\title{
A review of novel coronavirus disease (COVID-19): based on genomic structure, phylogeny, current shreds of evidence, candidate vaccines, and drug repurposing
}

\author{
S. Udhaya Kumar ${ }^{1}$ (1) $\cdot$ N. Madhana Priya ${ }^{2} \cdot$ S. R. Nithya ${ }^{2} \cdot$ Priyanka Kannan $^{2} \cdot$ Nikita Jain $^{1} \cdot$ D. Thirumal Kumar ${ }^{1,3}$ (1) \\ R. Magesh ${ }^{2} \cdot$ Salma Younes $^{4} \cdot$ Hatem Zayed $^{4}$ (D) $\cdot$ C. George Priya Doss ${ }^{1}$ (D)
}

Received: 25 August 2020 / Accepted: 16 March 2021 / Published online: 27 March 2021

(c) King Abdulaziz City for Science and Technology 2021

\begin{abstract}
Coronavirus disease (COVID-19) pandemic is instigated by severe acute respiratory syndrome coronavirus 2 (SARS-CoV-2). As of March 13, 2021, more than 118.9 million cases were infected with COVID-19 worldwide. SARS-CoV-2 is a positive-sense single-stranded RNA beta-CoV. Most COVID-19 infected individuals recover within 1-3 weeks. Nevertheless, approximately 5\% of patients develop acute respiratory distress syndrome and other systemic complications, leading to death. Structural genetic analyses of SARS-CoV-2 have shown genomic resemblances but a low evolutionary correlation to SARS-CoV-1 responsible for the 2002-2004 outbreak. The S glycoprotein is critical for cell adhesion and the entrance of the virus into the host. The process of cell entry uses the cellular receptor named angiotensin-converting enzyme 2 . Recent evidence proposed that the CD147 as a SARS-CoV-2's potential receptor. The viral genome is mainly held by two nonstructural proteins (NSPs), ORF1a and ORF1ab, along with structural proteins. Although NSPs are conserved among the $\beta C o V s$, mutations in NSP2 and NSP3 may play critical roles in transmitting the virus and cell tropism. To date, no specific/ targeted anti-viral treatments exist. Notably, more than 50 COVID-19 candidate vaccines in clinical trials, and a few being administered. Preventive precautions are the primary strategy to limit the viral load transmission and spread, emphasizing the urgent need for developing significant drug targets and vaccines against COVID-19. This review provides a cumulative overview of the genomic structure, transmission, phylogeny of SARS-CoV-2 from Indian clusters, treatment options, updated discoveries, and future standpoints for COVID-19.
\end{abstract}

Keywords COVID-19 - Drug repurposing · SARS-CoV-2 - SARS-CoV-2 genome · COVID-19 therapeutics · Vaccines · COVID-19 molecular diagnosis $\cdot$ Remdesivir $\cdot$ Hydroxychloroquine $\cdot$ Protease $\cdot$ India

\section{Introduction}

The coronavirus disease (COVID-19), which started in Wuhan, China, has spread across the world, affecting 218 countries and territories (Huang et al. 2020a; Wang et al.

S.Udhaya Kumar, N.Madhana Priya equally contributed.

R. Magesh

magesh.r@sriramachandra.edu.in

Hatem Zayed

hatem.zayed@qu.edu.qa

C. George Priya Doss

georgepriyadoss@ vit.ac.in

1 Department of Integrative Biology, School of BioSciences and Technology, Vellore Institute of Technology, Tamil Nadu, Vellore 632 014, India
2 Department of Biotechnology, Sri Ramachandra Institute of Higher Education and Research (DU), Tamil Nadu, Porur, Chennai 600116, India

3 Saveetha School of Engineering, Saveetha Institute of Medical and Technical Sciences, Chennai 602105, India

4 Department of Biomedical Sciences, College of Health and Sciences, QU Health, Qatar University, Doha, Qatar 
2020a; Li et al. 2020b; WHO 2020a). The novel severe acute respiratory syndrome coronavirus 2 (SARS-CoV-2) is responsible for the infection. The virus mainly affects the respiratory system leading to flu-like symptoms, including high temperature, coughing, and in more severe cases, breathing difficulty (Zou et al. 2020). Most patients recover in a period of $1-3$ weeks; however, approximately $5 \%$ develop severe symptoms that may progress to acute respiratory distress syndrome (ARDS) and respiratory failure, which may cause death. Besides, in patients at high risk, COVID-19 may lead to systemic inflammation, putting patients at risk of sepsis, cardiac injury, and organ dysfunction (Wang et al. 2020a). Older people ( $>60$ years) and people with other morbidities are at a higher risk of mortality (Wang et al. 2020a).

Coronaviruses (CoVs) belong to the family of Coronaviridae that encompass four genera that include alpha-, beta-, gamma-, and delta-CoVs. Alpha- and beta-CoVs infect mammals and humans, while gamma-CoVs infect birds and delta-CoVs infect birds and mammals. The two most known types of human CoVs are the beta-CoV OC43 and the alphaCoV 229E, both of which typically cause minor disease conditions, usually mild upper respiratory diseases that are self-limiting in individuals with a tolerable immune system (Sahin et al. 2020). Other human coronaviruses include the Middle East respiratory syndrome coronavirus (MERS-CoV, 2013), SARS-CoV-1 (2002), and the novel SARS-CoV-2, all of them belong to beta-CoVs, are transmitted through zoonotic transmission (from animals to humans), then spread among humans via close contact causing severe diseases ( $\mathrm{Li}$ et al. 2020a). Genomic characterization revealed that the sequences of SARS-CoV-2 exhibit high homology with that of the previously identified SARS-CoV-1 and weaker homology with MERS-CoV (Jaimes et al. 2020).

Nevertheless, the clinical and epidemiological characteristics of SARS-CoV-2 are not precisely the same as that of SARS-CoV-1. SARS-CoV-2 is highly transmittable compared to SARS-CoV-1, with a 2.6 primary reproduction number (R0) of spread, implying that the number of SARS-COV-2 positive cases increases exponentially (Hellewell et al. 2020). Moreover, SARS-CoV-2 has lower-level mortality compared to SARS-CoV-1. CoVs are enveloped viruses and have the most abundant RNA viral genome, with a length of 26 to $32 \mathrm{~kb}$ (Lu et al. 2020). The replication mechanism of CoVs is quite complicated to ease virus reproduction (Chen and Guo, 2016). The virion's primary connection with the host cell takes place between the $\mathrm{S}$ protein and its receptor. The positions of receptor binding domains (RBD) vary depending on the structural changes (Fehr and Perlman 2015). SARS-CoV-2 is spreading much faster than any other respiratory viruses. The incubation period of the virus ranges from 2-14 days, and a fraction of people likely transmit the infection without manifesting any symptoms of the disease (Martinez 2020). Currently, there are no effective treatments for COVID-19. Mutations in the genome of SARS-CoV-2 pose a significant challenge to researchers in drug and vaccine development (Xu et al. 2020a, b). Currently, there are more than 118.9 million cases have been recorded worldwide, with India listed in the 2nd place of the most confirmed cases (Table 1) (Kumar et al. 2020; Udhaya Kumar et al. 2020; MOHFW 2020; WHO 2020a). The top five states with the highest cases in India are provided in Table 1. Besides, we provided a country-wise full case report, cumulative total per 1 million population, the total number of deaths, and classification of transmission till March 13, 2021 (Supplementary Table 1) (WHO 2020a). This review aims to provide comprehensive insights into the genomic structure, transmission, treatment options, recent findings, and future standpoints towards COVID-19.

\section{Genomic structure}

$\mathrm{CoVs}$ are known to possess the largest genomes among all known RNA viruses, with a length ranging from 25 to $31 \mathrm{~kb}$. SARS-CoV-2 is a spherical enveloped consisting of singlestranded positive-sense RNA linked with a nucleoprotein inside a capsid comprising a matrix protein. The envelope has glycoprotein projections in a bear club-shape. The viral diameter is approximately $150-160 \mathrm{~nm}$. The SARS-CoV-2 exhibits high sequence similarity with the bat-SL-CoVZC45

Table 1 Confirmed COVID-19 cases along with the list of countries and states in India with the highest cases (https://covid19.who.int; https://mygov.in/covid-19/)

Confirmed cases over the date of 13th March, 2021118,268,575

Deaths over date 13th March, 2021—2,624,677

Americas

$52,386,995$

South-East Asia

$13,819,871$

Europe

$40,640,050$

Eastern Mediterranean

$6,793,641$

Africa

$2,932,557$

Western Pacific

$1,694,716$

Highest number of cases recorded across the globe

United States of America

$28,940,137$

India

$11,308,846$

Brazil

$11,202,305$

Russia Federation

$4,370,617$

The United Kingdom

$4,241,681$

Highest number of cases recorded across India

Maharashtra

$22,66,374$

Kerala

$10,85,663$

Karnataka

$9,57,584$

Andhra Pradesh

$8,91,178$

Tamil Nadu 
and bat-SL-CoVZXC2 $(\approx 88 \%$ and $87 \%$, respectively) while being less similar to SARS-CoV-1 and MERS-CoV $(\approx 79 \%$ and 50\%, respectively) (Lu et al. 2020).

A typical $\mathrm{CoV}$ genome contains protein-encoding domains (5' non-basic) consisting of two-third of genome replicase genes and 3' structural and non-essential accessory protein-coding domains (Masters 2006). The cells that contain the virus produce seven to nine viral-specific messenger RNAs with ends of 3' co-terminal (Masters 2006). The mRNAs' entirety conveys similar master sequences that span 70-90 nucleotides at the end of 5' (Lai et al. 1984, 1985). At their 5' ends, CoVs mRNAs have a leader sequence, which is common among them (Spaan et al. 1983), which comprises a transcription regulatory sequence (TRS-L) at the $3^{\prime}$ end that arranges part of the signal for transcription of the sub-genomic mRNA (Budzilowicz et al. 1985). The transcriptional regulatory sequences (TRSs) of all CoVs incorporated the conserved core sequences (CS), consisting of 6-8 nucleotides, along with $5^{\prime}$ and $3^{\prime}$ flanking sequences (Sola et al. 2005). Beta-CoVs comprise 5'-UCUAAAC-3', a heptameric consensus sequence. Replication occurs shortly after the virus enters the infective cell, followed by virion transfection via the generation of entire-length genomic and sub-genomic intermediate negative strands (Yount et al. 2000). There is a minimum of 6 open reading frames (ORFs) in the CoV structures' genomic and subgenomic regions. The SARS-CoV-2 genome contains 14 ORFs. The most significant part of the whole genome length is known to be the ORFa/b, the first of the ORFs, which encodes NSP116 (non-structural proteins), apart from Gamma-CoVs with the absence of NSP1. The polypeptides pp1a and pp1ab produced by -1 frameshift among ORF1a and ORF1b are processed virally determined main protease $\left(\mathrm{M}^{\mathrm{pro}}\right)$ or chymotrypsin-like protease $\left(3 \mathrm{CL}^{\mathrm{pro}}\right)$ and other minor proteases into 16 NSPs (Masters 2006).

As revealed by the whole-genome sequence alignment of the NSP-coding regions, there is approximately $58 \%$ identity among the varying $\mathrm{CoV}$ strains. About $43 \%$ identity in the structural protein-coding regions implies that NSPs form the genome's conserved regions, while structural proteins are more diverse (Chen et al. 2020). The NSPs aid in replication of the genome, proteolytic cleavage, and development of sub-genomic mRNA (14-16 final products prepared for coronaviruses) are inscribed on gene one inside the 5 '- proximate, which is two-third; whereas the structural proteins are inscribed on eight-nine genes inside the 3'- proximate, which is one-third of the coronavirus genome. The structural genes are positioned in the order of $5^{\prime}$ to $3^{\prime}$; they encode for viral proteins that include spike (S), envelope (E), membrane (M), and nucleocapsid $(\mathrm{N})$ proteins. Overall, the SARS-CoV-2 genome is about $25-31 \mathrm{~kb}$ in size with a spherical structure containing 9,860 amino acids. The genome encodes for 13 ORF's, out of which the first one-third codes for
NSPs, and the remaining make up the structural proteins. The CoV strains' identity varies in terms of the protein structure, where structural proteins show diverse structural characteristics.

\section{SARS-CoV-2 detection}

Nucleotide detection assays (NDA) such as Next Generation Sequencing (NGS) and RT-PCR detection technologies were implemented to detect SARS-CoV-2 (Shey et al. 2020; NGS 2020 , p. 19). Compared to the sequencing/NGS technologies, RT-PCR remains a cheaper method to detect SARSCoV-2 infection (Ai et al. 2020). The results can be achieved by assessing the expectorated sputum, bronchoalveolar lavage, or endotracheal aspirate samples acquired from the respiratory tracts (Lambert-Niclot et al. 2020). The tests are repeated for re-verification in positive results and negative cases with strong clinical suspicions (Hassan et al. 2020). The genetic material obtained from the mucus or salivary samples is amplified in the laboratory using RT-PCR. After retrieving a sufficient amount of the genetic material, the conserved regions of the $\mathrm{CoV}$ are determined. The probes have been used based on existing gene sequences published on Virological.org by the Shanghai Public Health Clinical Center \& Public Health School, Fudan University, Shanghai, China, and subsequently confirmed by other labs. In the COVID-19 positive cases, the tests are repeated to confirm the viral particles' clearance before the patient's discharge. The testing for the infection will differ based on the country (Dong et al. 2020). Several biosensors have been developed and identified for early SARS-CoV-2 detection (Behera et al. 2020).

Commercial NDA such as SARS-CoV-2 RNA detection kits was discovered, and nearly 37 commercial detection kits were approved by FDA (Health 2020). Non-commercial NDA, such as Loop-mediated isothermal amplification (LAMP) and RT-LAMP, is recognized as an optimistic method than PCR. It provides more sensitivity, specificity, product yield, and reaction efficiency (Ji et al. 2020). Consequently, several other detection methods have been employed, such as NP antigen detection assay, Antibody detection assays targeting SP and NP viral proteins (Ejazi et al. 2020; Li et al. 2020c; Guo et al. 2020). CT findings have been used controversially as a surrogate diagnostic test. Chest CT has a vital role in diagnosing COVID-19. COVID19 occurs with pneumonia symptoms in the initial stage, including dry cough, fever, chest congestion, and fatigue. Therefore, chest scan aids in the assessment of the disease extent condition and its follow-ups as it shows the patchy or diffuse asymmetric airspace opacities, which is an acute symptom of COVID-19. The initial scans showed a bilateral lung development pattern for around 40 patients out of 41

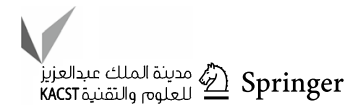


ICU patients (Hosseiny et al. 2020). The multifocal peripheral ground glass imaging results are highly suspicious of COVID-19, which might show a rapid change in a short duration (Table 2) (Li et al. 2020d).

\section{Structural proteins}

SARS-CoV-2 encompasses four types of structural proteins, namely $\mathrm{S}, \mathrm{E}, \mathrm{M}$, and $\mathrm{N}$ proteins. These four structural proteins share high sequence identity to that of SARS-CoV-1 and MERS-CoV. It is incorporated with hemagglutination (HE) and glycoprotein acetyl esterase, making SARSCoV-2 distinct from other CoVs (Cascella et al. 2020). The $\mathrm{S}$ proteins lie in the outermost sessions of the viral particle, ACE2, which is known to have an essential part in the action of transmembrane receptor recognition, which is used by the CoVs to make an entry into the host cell. Therefore, the host specificity and infectious nature of CoVs are determined chiefly by the $S$ proteins (Letko et al. 2020). Among all proteins within the virus structure, $\mathrm{M}$ protein is perhaps the most effective and is present in considerably various extents; it also provides the virus's shape. Figure 1 depicts the SARS-CoV-2 mechanism in the host cell.

On the other hand, inside the virion, E protein exists in the least quantity and helps release the infected cells' viral particles (Nal et al. 2005; Ashour et al. 2020). Simultaneously, the N protein attaches to the viral RNA, which is obligatory during viral assembly for wrapping the viral RNA into the viral components (Parameshwar et al. 2020). On the beta-CoV surface, the HE is located. It is similar to the influenza virus hemagglutinin. It provokes acetyl-esterase activity, characteristics of HE might enhance the pathogenesis and entrance of CoVs that involve proteins at its viral structure (Klausegger et al. 1999). CoVs use the S proteins to initiate the binding with the host cell. The binding activation is carried out by furin, an enzyme in several humans' organs, including the lungs, small intestine, and liver (Callaway et al. 2020). The $S$ protein and the furin enzyme activation are not the only factors; other human cells' elements make them more vulnerable to new SARS-CoV-2 infection. In human cells, it was shown that the $S$ protein needs to bind to ACE2, which allows SARS-CoV-2 to cause infection in human cells (Wrapp et al. 2020).

Experts suggested that furin inhibitors might be an effective therapeutic against COVID-19. Meanwhile, it is also recommended that blocking ACE2 might also be another feasible solution, stopping the $\mathrm{CoV}$ from cell entry (Coutard et al. 2020). In CoV, the RNA genome is enclosed in the $\mathrm{N}$ protein, further embedded into an envelope (Fan et al. 2005; McBride et al. 2014). The structural and NSPs are produced by sub-genomic + sense RNAs translation. After the formation of viral RNA components, the assembling of structural viral protein occurs in the virions. The budding and viral assembly occur in the endoplasmic reticulum-Golgi intermediate (Zhang et al. 2020).

\section{Common drug targets}

\section{Spike protein (S)}

The S protein is a $150 \mathrm{KDa}$ class I fusion transmembrane protein found in its outer portion. The protein contains an alpha-helical coiled structure and is highly glycosylated as it includes N-glycosylation sites from 21 to 35. It gathers as trimers giving a crown shape (corona; crown in Latin). They usually contain two N-terminal spaces labeled S1 that are liable for binding the receptor and a $\mathrm{C}$-terminal $\mathrm{S} 2$ space essential for fusion. The $\mathrm{S} 1$ spaces comprise two sub-domains: $\mathrm{N}$-terminal space and $\mathrm{C}$-terminal space. Both subdomains work as receptor restricting spaces and tie an assortment of protein and sugar (Robson 2020). The SARS$\mathrm{CoV}-2$ 's $\mathrm{S}$ protein attaches ten to multiple times more sturdily to the receptor ACE2 in people in contrast to that of the $\mathrm{S}$ protein of SARS-CoV-1 infection from 2002, which is liable for the simple spread of COVID-19 from individual to individual than different $\mathrm{CoV}$ s. The antibodies used against SARS-CoV-1 could not bind to the new SARS-CoV-2 S protein successfully; therefore, the vaccines or the antibodybased treatment should be unique for COVID-19. It is noteworthy that the proteases in host cells cleave the $\mathrm{S} 1$ domain instantly after the upstream of the S2 fusion peptide, which is anticipated to be the reason for protein activation through irreversible conformational changes (Walls et al. 2020).

\section{Envelope protein (E)}

The E protein is a small integral membrane protein but perhaps the most enigmatic. It is primarily expressed in infected cells during the replication cycle, and only a minute fraction is integrated with the virus envelope. The E protein is essential in virus assembly and maturation (Schoeman and Fielding 2019). They have three domains: hydrophilic amino acid terminus consist of 7-12 amino acids, the transmembrane hydrophobic domain containing 25 amino acids, and a long C-terminal end with the majority of proteins. The transmembrane domain (TMD) comprises two nonpolar, impartial amino acids: Leu and Val give solid hydrophobicity to E-protein. The central region [TMD] is uncharged, which is flanked towards one side by the amino acid negatively charged and on the opposite side via carboxy end of variable charges, which together give the $\mathrm{E}$ peptide gross net charge of zero (Schoeman and Fielding 2019). The E protein of SARS-CoV contains a restricting theme called postsynaptic thickness protein 95 (PSD95), Drosophila plate enormous tumor silencer (Dlg1), Zonula occludes-1 protein 


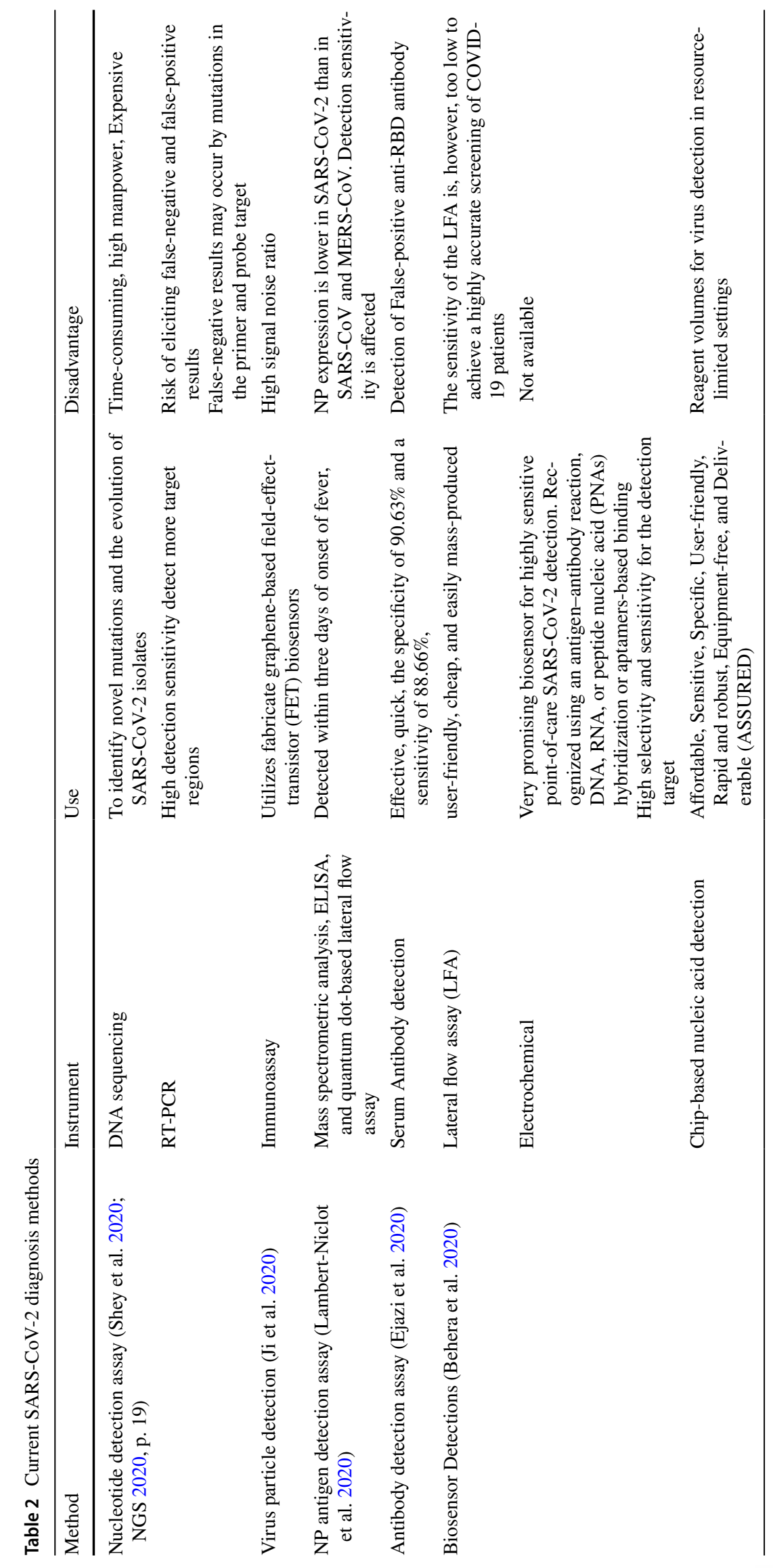


Fig. 1 The SARS-CoV-2 life cycle inside its host cell; starts when the $S$ protein binding occurs with the ACE2 receptor. After the binding process, the $S$ protein changes enable the fusion of the viral envelope via the cell membrane's endosomal pathway. Then the RNA is released from the SARS-CoV-2 inside the host cell. The translation of the RNA genome into the viral replicase polyproteins, which produces various viral particles. A sequence of subgenomic mRNAs are produced by discontinuous transcription and, at last, get translated into viral proteins. These viral proteins and RNA genome are organized in the endoplasmic reticulum and Golgi's virions, which are further transported through the vesicles, and finally, exocytosis occurs

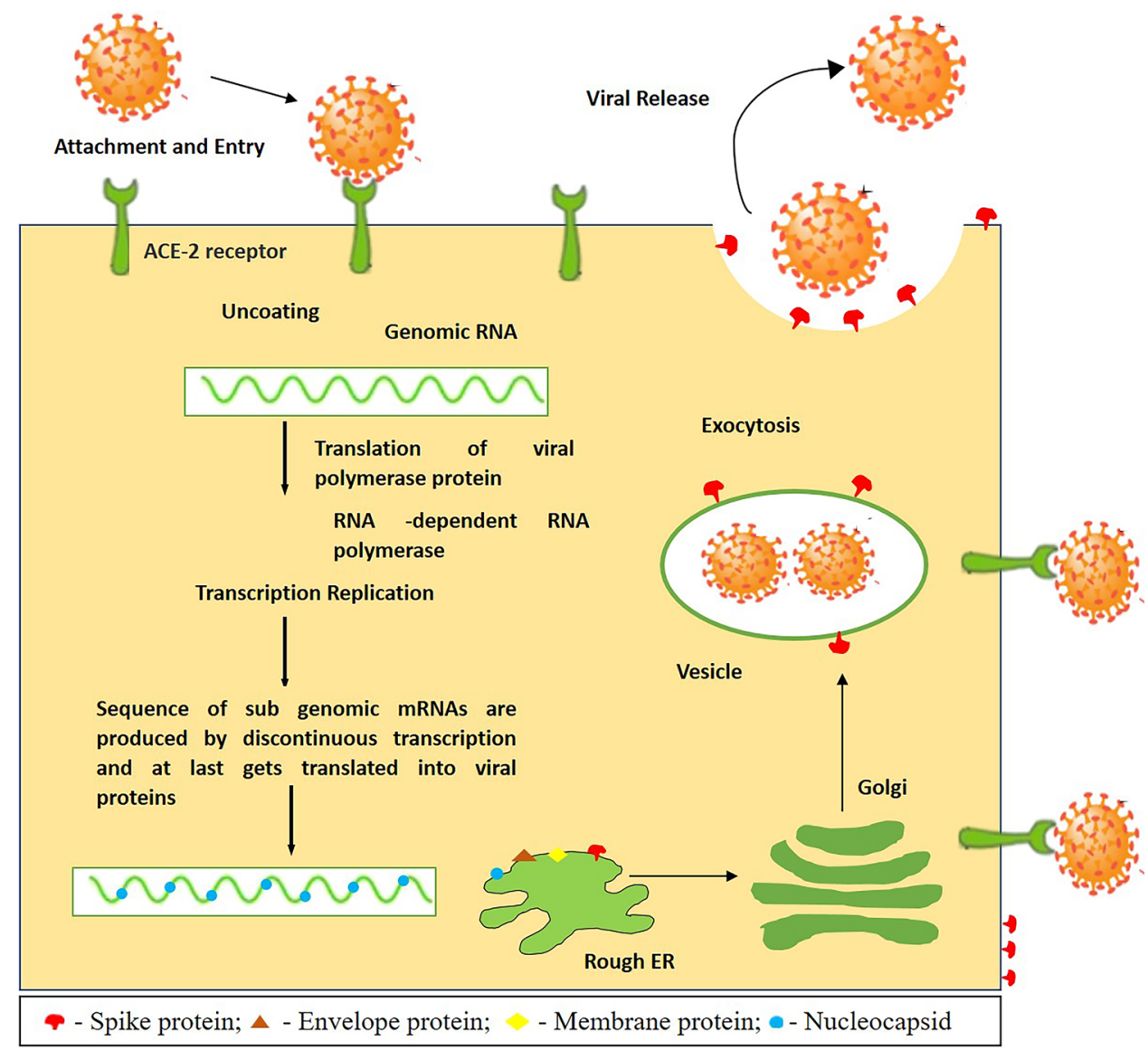

(zo-1), PBM found in the last four amino corrosive of the $\mathrm{C}$ end. PDZ area can tie to the $\mathrm{C}$-end of the cell connector protein engaged with have cell process that brings about the viral disease (Schoeman and Fielding 2019; Chan et al. 2020; Bianchi et al. 2020). Genetic analysis of the E protein revealed that the protein sequences in SARS-CoV-2 exhibit high identity from Pangolin and Bat isolate. Besides, evidence revealed a distinctive feature of $\mathrm{E}$ variants of SARSCoV-2 in the presence of Arg at position 69, which replaces Asp, Glu, and Gln in SARS-CoV-1 E homologous proteins. Besides, there is a deletion at position 70, which corresponds to Cys or Gly in the other homologous proteins and other existing variations at positions 37,55 to 56 , and at 72 (Bianchi et al. 2020).

\section{Membrane protein (M)}

The $\mathrm{M}$ protein is considered the most extensive protein in CoV's structural membrane. The membrane bilayer has the domain of short NH2-terminal in the outer part of the virus. It constitutes the cytoplasmic domain, i.e., the long $\mathrm{COOH}$ terminus in the viral particle's internal part. It has a vital role in forming the intracellular viral structures without the S protein (Mousavizadeh and Ghasemi 2020). It does not appear to have an enzymatic function, and it is not an ideal target either. Recent evidence revealed structural differences distinctive for SARS-CoV-2M protein that might be linked to the cross-species transmission and viral properties. Several variants were identified in SARS-CoV-2 M protein, including Ser2, Gly3, Val57, Arg89, 1le70, Ser85, and Met175 (Bianchi et al. 2020). Although multiple sequence alignment revealed high structural similarity ( 98\%) between M protein variants in SARS-CoV-2 and counterparts from Pangolin and Bats, the N-terminal position exhibited a variation in position four of the SARS-CoV-2's M protein, consisting of an insertion of a Ser residue. In contrast, in the homologous proteins, there was a deletion in the RaTG13 Bat and an Asp residue in Bat CoVZC45, CoVZXC21, and Pangolin MP789 isolates.

\section{Nucleocapsid protein $(\mathrm{N})$}

The N protein is primarily involved in binding to the virus's RNA genome, forming a shell around the nucleic acid. During the viral assembly process, there is a connection between the $\mathrm{N}$-protein and M-protein, assisting the RNA synthesis and folding, which is vital in the viral budding and disturbs the responses like cell cycle and translation in 
host cells. Recent evidence revealed that the SARS-CoV-2 N protein manifests high sequence similarity to SARS-CoV-1 $(\sim 90.5 \%)$ (Zeng et al. 2020). Nevertheless, structural differences that are distinctive for SARS-CoV-2 were reported. Most of the variants identified in the N protein of SARSCoV-2 were missense mutations (such as 203_204delinsKR, S194L, P13L, and S197L) and synonymous mutations (such as D128D and L139L), and fewer were deletion and insertion mutations (Koyama et al. 2020).

\section{Non-structural proteins (NSPs)}

The SARS-CoV genome encodes many proteins, including the replicase gene, a vital element of the genome $\mathrm{CoV}$, encoding for 16 NSPs that constitute two large polypeptides, PP1a PP1ab. Two types of cysteine proteases function on those PPs to activate the NSPs. Chymotrypsin-like cysteine protease cleaves the C-terminal end of these PPs, and the $\mathrm{M}^{\text {pro }}$ processes the N-terminal end, which is called papainlike protease $\left(\mathrm{PL}^{\mathrm{pro}}\right)$. $\mathrm{PL}^{\text {pro }}$ excises the first three cleavage sites in the PPs, while $\mathrm{CL}^{\text {pro }}$ cleaves the remaining 11 sites, resulting in 16 NSPs release (Prajapat et al. 2020a, b).

Researchers in Gladstone Institute, US, have identified SARS-CoV-2 protein-human protein interactions using affinity purification mass spectroscopy. They discovered 332 SARS-CoV-2 protein-human protein interactions, of which 66 druggable human proteins were identified to be targeted by 69 compounds, of which some are already FDA-approved and in clinical trials (Gordon et al. 2020). According to a recent study, the SARS-CoV-2 genome encodes 14 ORFs. In particular, 5' Orf1a/Orf1ab encodes polyprotein, which is autoproteolytically processed to 16 NSPs [NSP1-NSP16]. These form the replicase/transcriptase complex (RTC) such as NSP1, the main protease (NSP5), 2'O-methyltransferases (NSP10/NSP16), the primase complex (NSP7-NSP8), papain-like protease (NSP3), a helicase/triphosphatase (NSP13), an exoribonuclease (NSP14), the primary RdRp (NSP12), and an endonuclease (NSP15) (Li 2016). The NSP1 interacts with the DNA replication of the host pathway. The NSP5, NSP8, NSP13 interact with the epigenetic and gene expression regulatory pathway of the host. NSP6, NSP7, NSP10, NSP13, NSP15 interact with vesicle trafficking. NSP8 interacts with RNA processing and regulation of the host pathway. NSP9 interacts with the extracellular matrix and NSP8; NSP13 interacts with the host signaling pathway of the infection's replication mechanism that makes duplicates of its RNA genome (Chen et al. 2020). The original CoV' RdRp exists as mind-boggling with polymerase called NSP12 and some small proteins NSP7 and NSP8. It consists of a shape such as the right hand. The RdRp from SARS-CoV (2002) and SARS-CoV-2 having a similar dynamic site of RNA polymerization and indistinguishable amino corrosive arrangements. Scientists hypothesized that remdesivir drug inhibits the RdRp of SARS-CoV-2, for which the clinical trials have started to test the ability of this drug to the patients infected with SARS-CoV-2. However, it is not clear that how the mutant RdRp works with remdesivir, and a recent study found a potential compound with a higher affinity for both the native and mutant RdRp through virtual screening strategies (Thirumal et al. 2021). The S, $\mathrm{M}$, and $\mathrm{E}$ proteins form the envelope and protect the viral particle from external factors (Bianchi et al. 2020; Huang et al. 2020b; Thomas 2020). In short, protein structures play a crucial role in drug targets. The $\mathrm{S}$ glycoprotein structure of SARS-CoV-2 utilizes the ACE2 receptor of the host for cell entry, followed by other viral proteins exhibiting their role for the viral mechanism inside the host cell.

\section{Evolution and phylogenetic analysis of COVID-19 genomes}

A phylogenetic relationship of SARS-CoV-2's genome was reported in many studies; this method was applied to investigate the phylogenetic relationships among the genomes of CoVs, which investigate the developmental pathways and their ancestral/hereditary genome in the host organism (Forster et al. 2020; Jaimes et al. 2020; Nie et al. 2020). It is mainly applied to investigate human evolution; however, it was applied less in viral evolution (Forster et al. 2020). SARS-CoV-2 is an ancestry of beta-SARS-CoV that belongs to the Coronaviridae family. Unlike SARS-CoV, SARSCoV-2 possess a distinct evolution and proteolytically-sensitive activation loop, which is believed to be responsible for its high contagiousness and pathogenicity (Jaimes et al. 2020). Recent phylogenetic analyses demonstrated that SARS-CoV-2 was phylogenetically close to the RaTG13, accompanied by GD Pangolin SARSr-CoV, and by GX Pangolin SARSr-CoVs, and now by ZC45 and ZXC21, then by human SARS-CoV, and last by BM48-31 (Tang et al. 2020). As of March 13, 2021, more than 3,12,463 SAR-CoV-2 genome sequences are identified globally and available in the public domain. Based on the mutation marker, globally, six phylogenetic clades of SARS-CoV-2 were categorized (GH, S, GR, V, G, and L) (Jacob et al. 2020). Since the phylogenetic analysis of the SARS-CoV-2 genome was reported by Jacob et al. (2020), our review focused on discussing the relationship between the phylogeny from Indian clusters to understand the genomic evolution (Jacob et al. 2020). The sequences of SARS-CoV-2's genomes reported in India, which belong to the genus Coronaviridae, were extracted from the GISAID initiative. Many national institutions collected the SARS-CoV-2 samples from different regions of India; their genomes were sequenced and deposited in the GISAID initiative (GISAID 2020). For our phylogenetic study, alignments of nucleotides were constructed with the

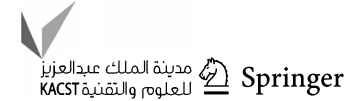


help of Multiple Alignment using Fast Fourier Transform (MAFFT), and Block Mapping and Gathering with Entropy (BMGE) algorithm was applied to compute the appropriate locations for phylogenetic analysis in the query multiple sequence alignment and followed by FastME to compute the pairwise distances and tree (Desper and Gascuel 2002; Junier and Zdobnov 2010; Criscuolo and Gribaldo 2010; Katoh and Standley 2013; Lefort et al. 2015; Lemoine et al. 2019). For further visualization of the output tree, we used the Interactive Tree Of Life (iTOL) (Letunic and Bork 2019) (Fig. 2). The SARS-CoV-2 genomes from Indian isolates exhibited a common PANGOLIN lineage, which is highly transmissible (B.1/B.1.1/B.1.36) with mutation (D614G); whereas, the B.6 lineage reported as a second common and least transmissible owing to the absence of mutation in $\mathrm{S}$ protein (Jacob et al. 2020; Banu et al. 2020; Koyama et al. 2020). Intriguingly, the Gujarat dominant linage B.1.36 contains one-three $\mathrm{S}$ protein mutations that would lead to higher infection rates.

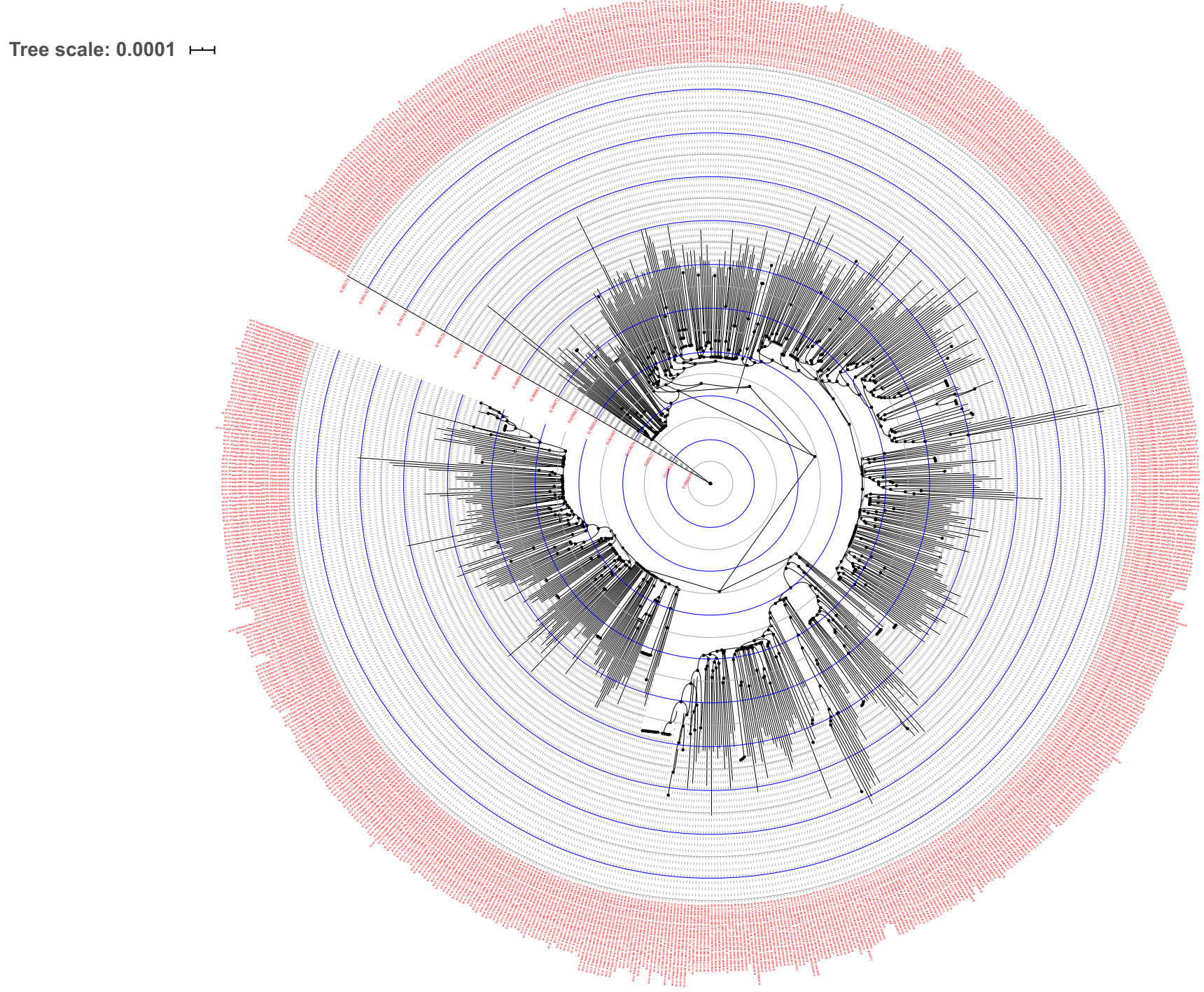

Fig. 2 Analysis of phylogeny relationship between the Indian SARSCoV-2 genomes of Coronaviridae from GISAID (https://www.gisaid. org/epiflu-applications/hcov-19-genomic-epidemiology/). Nearly 775 high-quality genomes were retrieved and conducted the phylogenetic analysis with NGPhylogeny (https://ngphylogeny.fr/). An interactive view of phylogeny was plotted using Interactive Tree Of Life (iTOL) (https://itol.embl.de/). The genome names (nodes) are displayed in red font, branch length from the root was provided in red font for each circle (blue and gray) with designated values. The internal node symbols were depicted in black dots (Display mode: Circular; Gap Penalty $=-1.53,+0.00,-0.12$; Tree scale: 0.0001 ) 


\section{Therapeutic management of COVID-19}

COVID-19 treatment requires clinical care, including aid in oxygen, fluid therapy, and support for other internal organs affected. Current potential therapeutics used against COVID-19 include antibodies, anti-virals, cell-based compounds, RNA-based compounds, anti-inflammatory agents, antimalarial agents, and protein-based antibiotics (Lu 2020). Figure 3 Summarizes current pre-clinical and clinical treatments available to treat COVID-19 (Milken Institute 2020). Table 3 includes a comprehensive description of the clinical evidence for the therapies being studied and Supplementary Table 2. Evidence showed that outpatients could be benefited from acquiring monoclonal antibodies against SARS-CoV-2 early. Bamlanivimab and casirivimab plus imdevimab monoclonal antibodies as anti-SARS-CoV-2 are provided via EUA for patients at high risk of disease progression.

Remdesivir (Veklury), an anti-viral agent, is the only FDA-approved drug for the COVID-19 treatment. The course of therapy of remdesivir was found to be effectively tolerated but is not efficacious in critical COVID19 cases (Ko et al. 2020; Wang et al. 2020b, c). Other anti-viral agents, including hydroxychloroquine and chloroquine, umifenovir, lopinavir-ritonavir, favipiravir, and oseltamivir, are currently being analyzed in vivo and in vitro (Table 3, Supplementary Table 2) (Wu et al. 2020; Biorender 2020). Oseltamivir joined with direct antiinfection utilization, has been utilized to treat patients with SARS-CoV-2 (Huang et al. 2020a). The adequacy

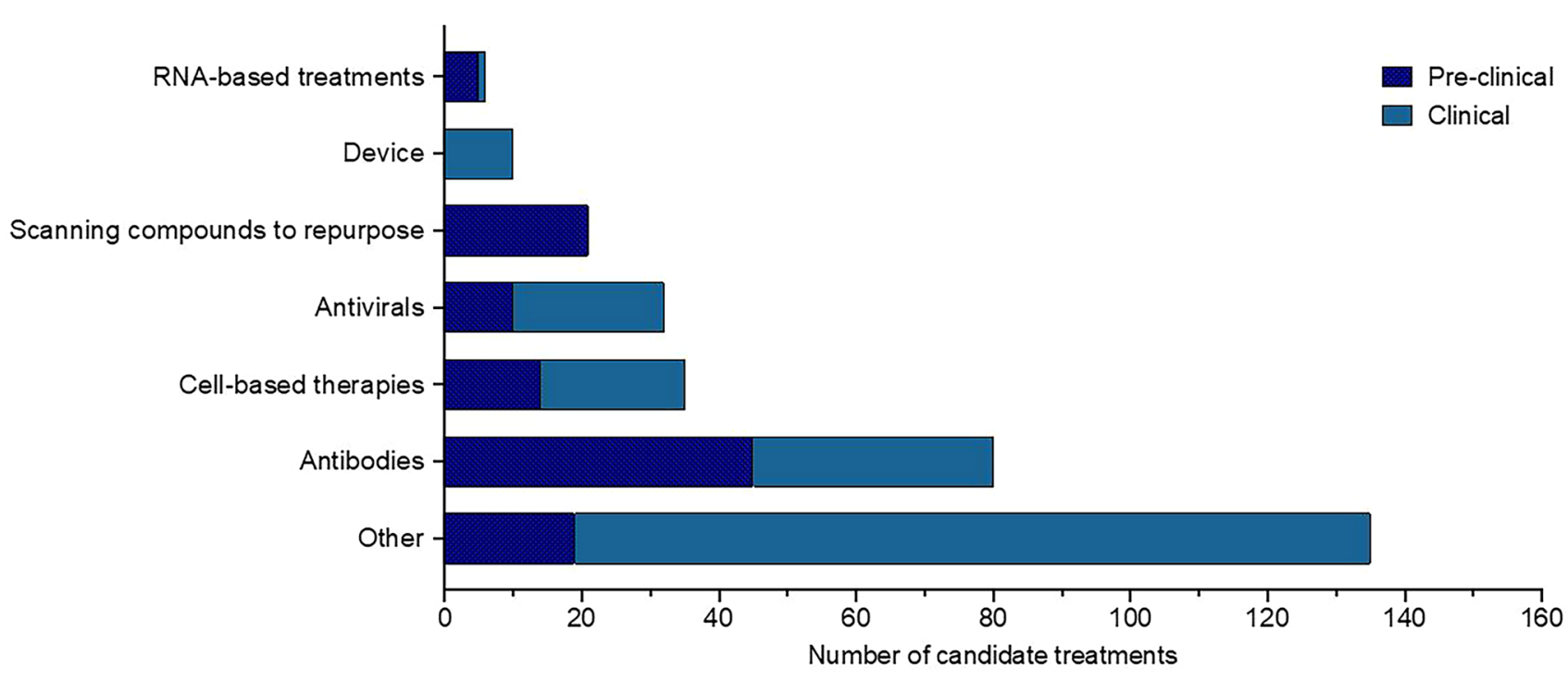

Fig. 3 COVID-19 therapeutic candidates in both clinical and preclinical development. Diverse categories of pre-clinical and clinical research COVID-19 therapeutic candidates are currently in develop- and safety measures of lopinavir-ritonavir and interferon- $\alpha$ $2 \mathrm{~b}$ in COVID-19 patients are still being investigated (Habibzadeh and Stoneman 2020). In vitro evidence using the antiparasitic drug, ivermectin has effectively worked as a potential therapeutic against SARS-CoV-2 in $48 \mathrm{~h}$. However, the safety and applicability in humans remain to be investigated (Caly et al. 2020). In hospitalized patients who need supplemental oxygen, corticosteroids, including dexamethasone, have been shown to enhance longevity, with the overall benefit seen in patients requiring mechanical ventilation. Hence, dexamethasone usage in this condition is highly recommended (Horby et al. 2020; Jeronimo et al. 2020; Angus et al. 2020; Tomazini et al. 2020).

\section{Why protease of COVID-19 be the best drug target?}

The crystal structures are always more reliable than computational models (Forrest et al. 2006). The crystal structure of the $\mathrm{M}^{\text {pro }}$ (PDB ID- 6LU7) could be the potential drug target with this aspect. It was not limited to this availability, but protease was essential in replicating the virus (Patick and Potts 1998). Replication occurs within the cytoplasm of the host cells that are infected. The coronaviruses' singlestranded RNA genome is released in the cytoplasm, where it is translated to form a replicase complex, which is then processed proteolytically into NSPs by viral proteases (van Boheemen et al. 2012; Kilianski et al. 2013). This makes it an excellent choice to inhibit the replicating virus and henceforth the viral assembly and its release. Coronavirus ment- source: COVID-19 vaccine and treatments tracker, Milken Institute (Milken Institute 2020) 
Table 3 COVID-19 candidate drug treatments in clinical trials (Phase III-IV)

\begin{tabular}{|c|c|c|c|}
\hline Drug Candidate & Organization & Technology & Stage \\
\hline Valsartan & $\begin{array}{l}\text { Radboud Universit, National University of Ire- } \\
\text { land, Galway, Ireland }\end{array}$ & Other & Phase IV \\
\hline Ebastine $^{a}$ & Mianyang Central Hospital & Antivirals & Phase IV \\
\hline Danoprevir $^{\mathrm{a}}$ & $\begin{array}{l}\text { Ascletis Pharmaceuticals Co., Ltd., The Ninth } \\
\text { Hospital of Nanchang }\end{array}$ & Antivirals & Phase IV \\
\hline Bivalirudin & Hamad Medical Corporation & Other & Phase IV \\
\hline Somatotropin & ClinAmygate & Dormant/Discontinued & Phase IV \\
\hline Darunavir $^{\mathrm{a}}$ & Multiple organizations & Antivirals & Phase III/IV \\
\hline Novaferon & Multiple organizations & Other & Phase III/IV \\
\hline Ravulizumab & Multiple organizations & Antibodies & Phase III/IV \\
\hline Carrimycin & Multiple organizations & Other & Phase III/IV \\
\hline Nintedanib & Multiple organizations & Other & Phase III/IV \\
\hline Telmisartan & Multiple organizations & Other & Phase II/III/IV \\
\hline Tocilizumab $^{\mathrm{a}}$ & Multiple organizations & Antibodies & Phase II/III/IV \\
\hline Corticosteroid Therapy ${ }^{\mathrm{a}}$ & Multiple organizations & Other & Phase II/III/IV \\
\hline Tissue plasminogen activator & Multiple organizations & Other & Phase II/III/IV \\
\hline $\begin{array}{l}\text { Granulocyte-Macrophage Colony-Stimulating } \\
\text { Factor }\end{array}$ & Multiple organizations & Other & Phase II/III/IV \\
\hline Anakinra $^{\mathrm{a}}$ & Multiple organizations & Other & Phase II/III/IV \\
\hline Nitazoxanide $^{\mathrm{a}}$ & Multiple organizations & Other & Phase II/III/IV \\
\hline Eicosapentaenoic Acid Free Fatty Acid & Multiple organizations & Other & Phase II/III/IV \\
\hline Rivaroxaban $^{\mathrm{a}}$ & Multiple organizations & Other & Phase II/III/IV \\
\hline Interferon beta- $1 \mathrm{a}^{\mathrm{a}}$ & Multiple organizations & Other & Phase II/III/IV \\
\hline Baricitinib $^{\mathrm{a}}$ & Multiple organizations & Other & Phase II/III/IV \\
\hline Candesartan $^{\mathrm{a}}$ & Multiple organizations & Other & Phase II/III/IV \\
\hline Doxycycline $^{a}$ & Multiple organizations & Other & Phase II/III/IV \\
\hline Sofosbuvir $^{\mathrm{a}}$ & Multiple organizations & Antivirals & Phase II/III/IV \\
\hline Ledipasvir $^{\mathrm{a}}$ & Multiple organizations & Antivirals & Phase II/III/IV \\
\hline (Hydroxy)Chloroquine $^{\mathrm{a}}$ & Multiple organizations & Other & Phase I/II/III/IV \\
\hline Lopinavir $^{\mathrm{a}}$ & Multiple organizations & Antivirals & Phase I/II/III/IV \\
\hline Favipiravir $^{\mathrm{a}}$ & Multiple organizations & Antivirals & Phase I/II/III/IV \\
\hline Sarilumab $^{\mathrm{a}}$ & Multiple organizations & Antibodies & Phase I/II/III/IV \\
\hline Convalescent plasma & Multiple organizations & Antibodies & Phase I/II/III/IV \\
\hline Intravenous Immunoglobulin & Multiple organizations & Antibodies & Phase I/II/III/IV \\
\hline Ritonavir $^{\mathrm{a}}$ & Multiple organizations & Antivirals & Phase I/II/III/IV \\
\hline Camostat Mesylate $^{\mathrm{a}}$ & Multiple organizations & Other & Phase I/II/III/IV \\
\hline Interferon alpha & Multiple organizations & Other & Phase I/II/III/IV \\
\hline Losartan $^{\mathrm{a}}$ & Multiple organizations & Other & Phase I/II/III/IV \\
\hline Ivermectin $^{\mathrm{a}}$ & Multiple organizations & Other & Phase I/II/III/IV \\
\hline Azithromycin $^{\mathrm{a}}$ & Multiple organizations & Other & Phase I/II/III/IV \\
\hline Low Molecular Weight Heparin ${ }^{a}$ & Multiple organizations & Other & Phase I/II/III/IV \\
\hline Bamlanivimab & Multiple organizations & Antibodies & Phase I/II/III/IV \\
\hline $\mathrm{N}$-acetylcysteine & Multiple organizations & Other & Phase I/II/III/IV \\
\hline Povidone-Iodine & Multiple organizations & Other & Phase I/II/III/IV \\
\hline Dexamethasone $^{\mathrm{a}}$ & Multiple organizations & Other & Phase I/II/III/IV \\
\hline Otilimab & GlaxoSmithKline & Antibodies & Phase III \\
\hline $\mathrm{ASC}^{2} 9^{\mathrm{a}}$ & Multiple organizations & Antivirals & Phase III \\
\hline Azvudine & Multiple organizations & Antivirals & Phase III \\
\hline Remestemcel-L & $\begin{array}{l}\text { Mesoblast, Inc, Icahn School of Medicine at } \\
\text { Mount Sinai }\end{array}$ & Cell-based therapies & Phase III \\
\hline
\end{tabular}


Table 3 (continued)

\begin{tabular}{|c|c|c|c|}
\hline Drug Candidate & Organization & Technology & Stage \\
\hline $\mathrm{CD} 24 \mathrm{Fc}$ & OncoImmune, Inc & Other & Phase III \\
\hline INOpulse & Bellerophon & Device & Phase III \\
\hline Cobicistat $^{\mathrm{a}}$ & Multiple Organizations & Antivirals & Phase III \\
\hline Tradipitant & Vanda Pharmaceuticals & Other & Phase III \\
\hline Brensocatib & Insmed Inc., University of Dundee & Other & Phase III \\
\hline Pacritinib & CTI Biopharma & Other & Phase III \\
\hline Almitrine & Multiple organizations & Other & Phase III \\
\hline Levilimab & Biocad & Antibodies & Phase III \\
\hline Prasugrel & $\begin{array}{l}\text { Azienda Ospedaliera Universitaria Integrata } \\
\text { Verona, University of Milan }\end{array}$ & Other & Phase III \\
\hline NK-1R antagonist & $\begin{array}{l}\text { University of Lahore, Bahria International } \\
\text { Hospital }\end{array}$ & Other & Phase III \\
\hline Rosuvastatin $^{\mathrm{a}}$ & Yale University & Other & Phase III \\
\hline $\mathrm{XC} 221$ & RSV Therapeutics LLC & Antivirals & Phase III \\
\hline Broncho-Vaxom & Multiple organizations & Other & Phase III \\
\hline Bucillamine & Revive Therapeutics, Ltd & Other & Phase III \\
\hline Losmapimod & Fulcrum Therapeutics & Other & Phase III \\
\hline Edoxaban $^{\mathrm{a}}$ & $\begin{array}{l}\text { University Hospital Inselspital, Berne, Daiichi } \\
\text { Sankyo Europe, GmbH, a Daiichi Sankyo } \\
\text { Company }\end{array}$ & Other & Phase III \\
\hline Brexanolone & Sage Therapeutics & Other & Phase III \\
\hline $\mathrm{NA}-831^{\mathrm{a}}$ & NeuroActiva, Inc., Biomed Industries, Inc & Other & Phase III \\
\hline Nicotine & Assistance Publique-Hôpitaux de Paris & Other & Phase III \\
\hline Lidocaine & Multiple Organizations & Other & Phase III \\
\hline Fenofibrate & $\begin{array}{l}\text { Hebrew University of Jerusalem, Barzilai Medi- } \\
\text { cal Center }\end{array}$ & Other & Phase III \\
\hline Fluvoxamine & $\begin{array}{l}\text { Washington University School of Medi- } \\
\text { cine, Covid-19 Early Treatment Fund }\end{array}$ & Other & Phase II/III \\
\hline Tranexamic Acid & University of Alabama at Birmingham & Other & Phase II/III \\
\hline Lenzilumab & Multiple organizations & Antibodies & Phase II/III \\
\hline Bevacizumab & Multiple organizations & Antibodies & Phase II/III \\
\hline Siltuximab $^{\mathrm{a}}$ & Multiple organizations & Antibodies & Phase II/III \\
\hline Eculizumab & Multiple organizations & Antibodies & Phase II/III \\
\hline Canakinumab & Multiple organizations & Antibodies & Phase II/III \\
\hline Emapalumab & Swedish Orphan Biovitrum & Antibodies & Phase II/III \\
\hline IFX-1 & Multiple organizations & Antibodies & Phase II/III \\
\hline Truvada $^{\mathrm{a}}$ & Multiple organizations & Antivirals & Phase II/III \\
\hline VIR-7831 & Vir Biotechnology, Inc., GlaxoSmithKline & Antibodies & Phase II/III \\
\hline Multipotent Adult Progenitor Cells & Athersys, Inc & Cell-based therapies & Phase II/III \\
\hline Ifenprodil & Algernon Pharmaceuticals, Novotech & Other & Phase II/III \\
\hline Nafamostat & Multiple organizations & Other & Phase II/III \\
\hline Colchicine $^{\mathrm{a}}$ & Multiple organizations & Other & Phase II/III \\
\hline Selinexor & $\begin{array}{l}\text { Karyopharm therapeutics, Peter MacCallum } \\
\text { Cancer Centre, Australia }\end{array}$ & Other & Phase II/III \\
\hline Vazegepant & Biohaven Pharmaceuticals, Inc & Other & Phase II/III \\
\hline Dapagliflozin ${ }^{\mathrm{a}}$ & Multiple organizations & Other & Phase II/III \\
\hline Imatinib $^{\mathrm{a}}$ & Multiple organizations & Other & Phase II/III \\
\hline DAS181 & Multiple organizations & Antivirals & Phase II/III \\
\hline Dipyridamole & Multiple organizations & Other & Phase II/III \\
\hline $\mathrm{ABX} 464$ & Abivax S.A & Other & Phase II/III \\
\hline Dociparastat sodium & Chimerix & Other & Phase II/III \\
\hline
\end{tabular}


Table 3 (continued)

\begin{tabular}{|c|c|c|c|}
\hline Drug Candidate & Organization & Technology & Stage \\
\hline EDP1815 & $\begin{array}{l}\text { Cambridge University Hospitals NHS Foundation } \\
\text { Trust, Evelo Biosciences, Inc }\end{array}$ & Other & Phase II/III \\
\hline Mavrilimumab & Multiple organizations & Antibodies & Phase II/III \\
\hline Levamisole $^{\mathrm{a}}$ & Multiple organizations & Other & Phase II/III \\
\hline Secukinumab & $\begin{array}{l}\text { Assistance Publique-Hôpitaux de Paris, } \\
\text { Lomonosov Moscow State University Medical } \\
\text { Research and Educational Center }\end{array}$ & Antibodies & Phase II/III \\
\hline RTB101 & Restorbio Inc., National Institute on Aging & Other & Phase II/III \\
\hline Tacrolimus $^{\mathrm{a}}$ & $\begin{array}{l}\text { Hospital Universitari de Bellvitge, Institut } \\
\text { d'Investigació Biomèdica de Bellvitge }\end{array}$ & Other & Phase II/III \\
\hline Hyperbaric chamber & Multiple organizations & Device & Phase II/III \\
\hline Opaganib & $\begin{array}{l}\text { RedHill Biopharma Limited, Shaare Zedek Medi- } \\
\text { cal Center }\end{array}$ & Other & Phase II/III \\
\hline Lactoferrin & Multiple organizations & Other & Phase II/III \\
\hline Clazakizumab & Multiple organizations & Antibodies & Phase II/III \\
\hline Ambrisentan $^{\mathrm{a}}$ & $\begin{array}{l}\text { Cambridge University Hospitals NHS Foundation } \\
\text { Trust }\end{array}$ & Other & Phase II/III \\
\hline PTC299 & PTC therapeutics & Other & Phase II/III \\
\hline Daclatasvir $^{\mathrm{a}}$ & Multiple organizations & Antivirals & Phase II/III \\
\hline BDB-001 & $\begin{array}{l}\text { Staidson (Beijing) Biopharmaceuticals Co., Ltd, } \\
\text { Beijing Defengrui Biotechnology Co. Ltd }\end{array}$ & Other & Phase II/III \\
\hline Olokizumab & Multiple organizations & Antibodies & Phase II/III \\
\hline NA- $831^{\mathrm{a}}$ & NeuroActiva, Inc & Other & Phase II/III \\
\hline Atazanavir $^{\mathrm{a}}$ & Multiple organizations & Antivirals & Phase II/III \\
\hline RPH-104 & Multiple organizations & Other & Phase II/III \\
\hline RESP301 & Thirty respiratory limited & Other & Phase II/III \\
\hline Atorvastatin & Multiple organizations & Other & Phase II/III \\
\hline Acetylsalicylic acid & Multiple organizations & Other & Phase II/III \\
\hline BIO101 & Biophytis & Other & Phase II/III \\
\hline TD139 & University of Edinburgh, University of Oxford & Other & Phase II/III \\
\hline Melatonin & Multiple Organizations & Other & Phase II/III \\
\hline Itolizumab & Biocon Limited, Equillium & Antibodies & Phase II/III \\
\hline Apremilast $^{\mathrm{a}}$ & QuantumLeap Healthcare Collaborative, Amgen & Other & Phase II/III \\
\hline Bardoxolone methyl & $\begin{array}{l}\text { NYU Langone Health, Reata Pharmaceuticals, } \\
\text { Inc }\end{array}$ & Other & Phase II/III \\
\hline INM005 & Inmunova S.A. & Antibodies & Phase II/III \\
\hline Bicalutamide & $\begin{array}{l}\text { University of Florida, Sidney Kimmel Compre- } \\
\text { hensive Cancer Center at Johns Hopkins }\end{array}$ & Other & Phase II/III \\
\hline Metformin $^{\mathrm{a}}$ & Multiple organizations & Other & Phase II/III \\
\hline IMU- $838^{\mathrm{a}}$ & Multiple organizations & Other & Phase II/III \\
\hline Triazavirin & Multiple organizations & Antivirals & Phase II/III \\
\hline Furosemide & $\begin{array}{l}\text { Queen's University, University Health Network, } \\
\text { Toronto }\end{array}$ & Other & Phase II/III \\
\hline Recombinant Nematode Anticoagulant Protein c2 & $\begin{array}{l}\text { ARCA Biopharma, Inc., Colorado Prevention } \\
\text { Center }\end{array}$ & Other & Phase II/III \\
\hline Remdesivir $^{\mathrm{b}}$ & Multiple Organizations & Antivirals & Phase I/II/III \\
\hline Thymosin & Multiple Organizations & Other & Phase I/II/III \\
\hline Meplazumab & $\begin{array}{l}\text { Tang-Du Hospital, Jiangsu Pacific Meinuoke Bio } \\
\text { Pharmaceutical Co Ltd }\end{array}$ & Antibodies & Phase I/II/III \\
\hline Ribavirin & Multiple organizations & Antivirals & Phase I/II/III \\
\hline Ruxolitinib & Multiple organizations & Other & Phase I/II/III \\
\hline Nitric Oxide & Multiple organizations & Other & Phase I/II/III \\
\hline
\end{tabular}


Table 3 (continued)

\begin{tabular}{|c|c|c|c|}
\hline Drug Candidate & Organization & Technology & Stage \\
\hline Aviptadil & Multiple organizations & Other & Phase I/II/III \\
\hline Niclosamide $^{\mathrm{a}}$ & Multiple organizations & Other & Phase I/II/III \\
\hline Interferon beta- $1 \mathrm{~b}^{\mathrm{a}}$ & Multiple organizations & Other & Phase I/II/III \\
\hline Molnupiravir & Multiple organizations & Antivirals & Phase I/II/III \\
\hline Angiotensin 1-7 & Multiple organizations & Other & Phase I/II/III \\
\hline DNases & Multiple organizations & Other & Phase I/II/III \\
\hline REGN-COV2 & Regeneron Pharmaceuticals & Antibodies & Phase I/II/III \\
\hline SCTA01 & Sinocelltech Ltd & Antibodies & Phase I/II/III \\
\hline Fostamatinib & Multiple organizations & Other & Phase I/II/III \\
\hline CT-P59 & Celltrion & Antibodies & Phase I/II/III \\
\hline Umifenovir $^{\mathrm{a}}$ & Multiple organizations & Antivirals & Phase I/IV \\
\hline Oseltamivir $^{\mathrm{a}}$ & Multiple organizations & Antivirals & Phase I/III/IV \\
\hline Famotidine & Multiple organizations & Other & Phase I/III/IV \\
\hline Cyclosporine & Multiple organizations & Other & Phase I/II/IV \\
\hline TY027 & Tychan Pte Ltd & Antibodies & Phase I/III \\
\hline Bromhexine $^{\mathrm{a}}$ & Multiple organizations & Other & Phase I/III/IV \\
\hline Therapeutic Plasma Exchange & Multiple organizations & Other & Phase II/IV \\
\hline Chlorhexidine & NYU Langone Health, Ohio State University & Other & Phase II/IV \\
\hline AZD7442 & Multiple organizations & Antibodies & Phase I/III \\
\hline
\end{tabular}

${ }^{a}$ May be used in combination with other therapeutics. Clinical trials mentioned contain this included drug in the regimen

${ }^{b}$ FDA approved for COVID-19 treatment. This Table was last updated on December 14, 2020. Treatments that have not reached phase III clinical trials are not shown in this Table— source BioRender Vaccine and therapeutics Tracker (Biorender 2020)

proteases are known to be multifunctional. Studies have shown that coronavirus has the DUB and deISGylating to evade innate immune systems (Komander et al. 2009; Jeon et al. 2010). Some of the mechanisms that the virus adapts to evade the immune system include (1) inhibition of the poly I: $\mathrm{C}$ by the protease leading to the activation of the TRIF and further the NF- $\mathrm{KB}$ signaling. (2) Downregulation of the IFR3 phosphorylation, thereby preventing its dimerization, results in the signal cascade's termination. (3) Protease is also known to repress the IFN signalling. (4) Protease

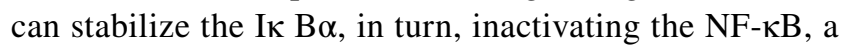
transcription factor for the activation of the inflammatory cytokines. (5) Activation of NF-kB by TNF $\alpha$ is blocked by protease (Devaraj et al. 2007; Frieman et al. 2009; Clementz et al. 2010). Protease inhibitors can bind to the protease, thereby activating the signaling pathway and release of proinflammatory cytokines, and hence are an excellent choice for the anti-viral agent.

The main protease of SARS-CoV-2, referred to as the $3 \mathrm{C}$-like protease $\left(3 \mathrm{CL}^{\mathrm{pro}}\right)$, was identified as a target for postinfection drugs in March 2020. 3CL ${ }^{\text {pro }}$ enzyme plays a crucial role in the replication and life cycle of the virus. The human immunodeficiency viruses (HIV) protease inhibitors lopinavir and ritonavir have evidence of activity against the coronaviruses, including SARS-CoV and MERS-CoV (Li and Clercq 2020; Kupferschmidt et al. 2020). They have recently been proposed as a potential combination therapy against COVID-19 (Table 3 and Supplementary Table 2) (Kupferschmidt et al. 2020; Mullard 2020; Mishra et al. 2020). Nevertheless, a recent preliminary study in China of lopinavir/ ritonavir combination therapy found no effect in people hospitalized for COVID-19 (Cao et al. 2020). Efforts are currently directed towards identifying novel protease inhibitors that target the protease $3 \mathrm{CL}^{\text {pro }}$, such as GC376 (Supplementary Table 2) (Ramajayam et al. 2011; Morse et al. 2020; Liu et al. 2020). Other protease inhibitors include bromhexine hydrochloride (Table 3), which reduced patients' mortality rate with COVID-19 (Ansarin et al. 2020). Besides, it can reduce infection, which could be used to treat COVID-19 as a prophylactic treatment (Ansarin et al. 2020). Oral camostat mesylate is another prophylactic option for treatment COVID-19 treatment (Table 3 and Supplementary Table 2). Research findings have shown that it prevents the SARS-CoV-2 entry into the hosts, indicating its potential effectiveness in treatment (Hoffmann et al. 2020). 


\section{Role of drug repurposing in the field of drug discovery}

The global pharmaceutical industries face many challenges, including attenuation of the drugs and higher cost due to an increased number of years to bring a drug to the market and changes in the regulatory requirements (Pammolli et al. 2011; Waring et al. 2015). Drug repurpositioning is also known as the reprofiling or repositioning of drugs. It is an approach to identify novel uses of the already established or approved drug to treat a new disease other than the first indication (Ashburn and Thor 2004). In the early days, drug repurposing has been mostly expedient; once a drug is discovered, and the drug shows its effect on different sites other than the targeted site, it was taken for commercial manipulation (Pushpakom et al. 2019). The advantages of the drug repurposing approaches are: (1) the risk of drug failure is shallow because the drug used for repositioning was already proven to be reasonably safe enough in pre-clinical, experimental models and also in the clinical trials; (2) the time entailed for the development of a drug can also be reduced because of the pre-clinical testing and safety assessment, which has already been completed; and (3) only less fund is required for the development of a repurposing drug, depending on the stage and also the procedure of development (Breckenridge and Jacob 2019). The regulatory and phase III trial cost may remain the same, but the cost of phase I and II trial can be reduced or saved.

\section{Drug repurposing approach to treat COVID-19}

Researchers have started testing existing anti-viral drugs that are widely used to treat HIV in hopes that they might be able to fight the COVID-19 (Supplementary Table 2). A randomized controlled trial of the combination of ritonavir and lopinavir, an anti-HIV drug, is also being tested (Huang et al. 2020a). The trials with other identified anti-viral drugs against other viral diseases like Ebola may benefit from another anti-viral testing. The use of marketed drugs whose safety profile is known could be used as adjuncts to monotherapy. Combinatorial therapies with cyclosporin, ribavirin, lopinavir-ritonavir, interferon beta- $1 \mathrm{~b}$, remdesivir, monoclonal antibodies can be tested to prevent or curb the infection (Beigel et al. 2019; Singh et al. 2020). The replication of coronavirus and release in cytoplasm forms a replicase complex that is then processed proteolytically into NSPs by viral proteases (van Boheemen et al. 2012; Kilianski et al. 2013). This makes it an excellent choice to inhibit replicating the virus and henceforth the viral assembly and its release. Since no specific drug or vaccine is identified and approved when we wrote the manuscript for COVID-19 treatment, the best medication to be followed is a repurposing of anti-viral drugs. There must be an imminent need to control the widespread SARS-CoV-2 transmission repurposing as an effective treatment to prevent the rapid spread.

\section{Current COVID-19 vaccine candidates}

Several promising candidate vaccines have been developed by researchers, which have shown efficacy in phase trials II and III; 166 candidate vaccines are in pre-clinical evaluation, and 56 vaccines are in the clinical evaluation as of December 16, 2020. Figure 4 Summarizes candidate COVID-19 vaccines in pre-clinical and clinical trials (WHO 2020b). A detailed description of the vaccines can be found in Table 4 and Supplementary Table 3. Four candidate vaccines have cleared phase III trials (Moderna's mRNA-1273, Pfizer/ BioNTech's BNT162b2, Gamaleya's Sputnik V vaccine University-Oxford \& AstraZeneca's AZD1222). On December 11, 2020, and December 18, 2020, the U.S. Food and Drug Administration (FDA) issued emergency use authorization (EUA) for the Pfizer-BioNTech and Moderna COVID-19 Vaccines, respectively (Table 4, Supplementary Table 3).

\section{Future outlook}

The on-going outbreak of COVID-19 induced by the novel SARS-CoV-2 has put the world on red caution as it continues spreading and causing more fatalities. Exploration endeavors are being completed to diminish the SARS-CoV-2 and its variants from spreading. Discovering medications is commonly known as a long process that takes time. Different computer-aided drug designs (CADD) are assessed as promising strategies among all these structure-based medication plans. Ligand-based medication configuration approaches are known as valuable and ground-breaking procedures in tranquilize revelation advancement. These strategies can be 


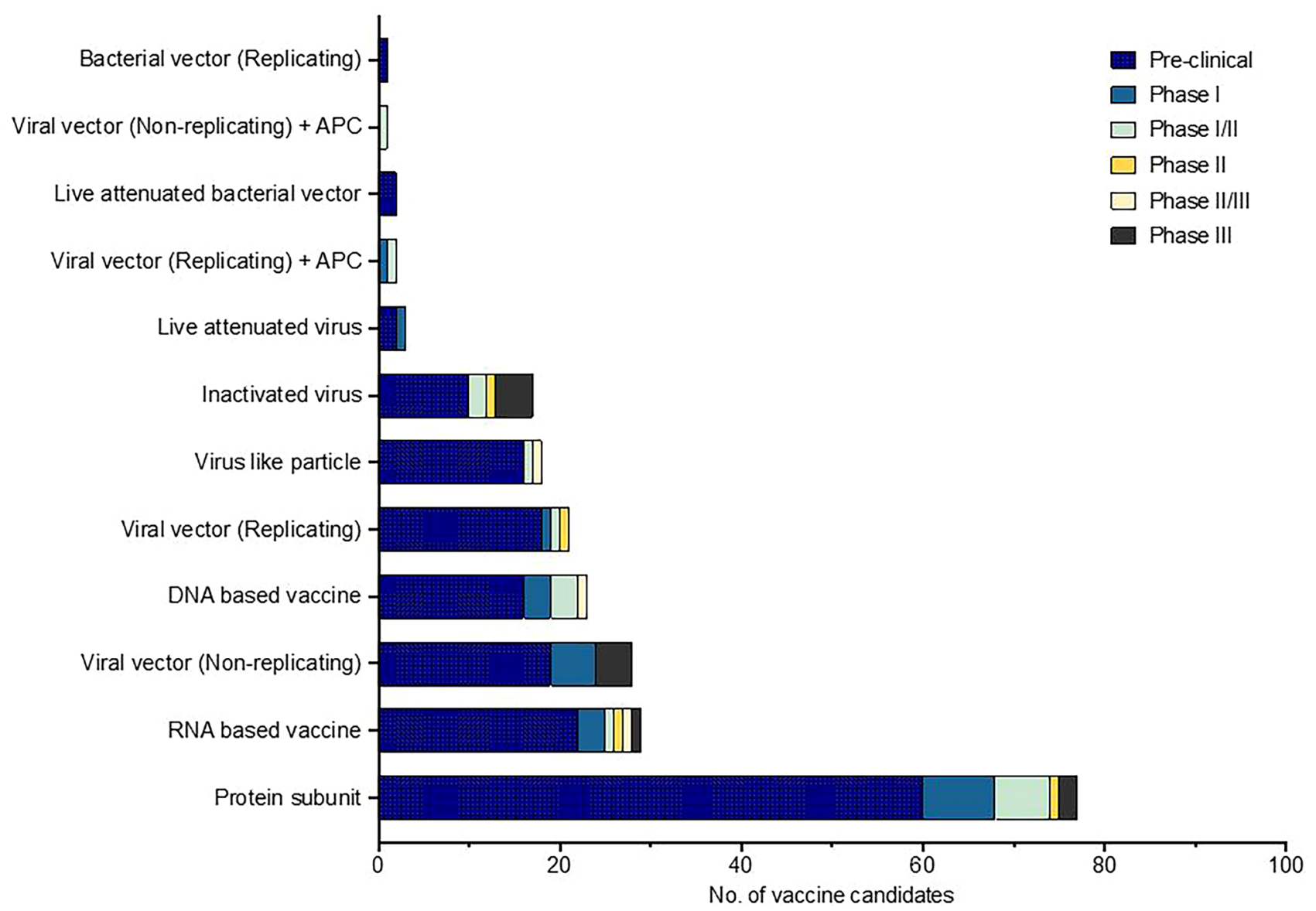

Fig. 4 Candidate COVID-19 vaccines in both clinical and pre-clinical development. Diverse categories of pre-clinical and clinical research COVID-19 vaccine candidates are currently in development. APC:

applied with atomic docking to virtual screening for potential lead identification and enhancement. Currently, computational instruments are utilized in pharmaceutical ventures and examination regions to improve the medication disclosure and advancement pipeline's viability and adequacy. On the other hand, understanding the host-virus relationships and transcriptomic profiles of COVID-19 patients will prioritize gene targets that will lead to developing therapeutic drugs (Alsamman and Zayed 2020).

\section{Conclusion}

The COVID-19 outbreak has put health systems on a red alert as it quickly spreads globally. Old individuals and patients with chronic diseases are at high risk of developing severe symptoms and potential death from COVID-19. Researchers worldwide are struggling and trying hard to antigen-presenting cells. Source: World Health Organization (WHO). The COVID-19 Candidate Vaccine Landscape (WHO 2020b)

find effective treatments for COVID-19. In addition, drug repurposing can be achieved using existing FDA-approved anti-viral drugs for COVID-19. Since the described drugs are FDA-approved, their efficacy in treating the infection is expected to be less toxic to patients. This could lower the disease's severity in elderly patients and protect lives. The $\mathrm{M}^{\text {pro }}, \mathrm{S}$ glycoproteins, $\mathrm{PL}^{\text {pro }}, \mathrm{RdRp}$, and $3 \mathrm{CL}^{\text {pro }}$ of COVID19 can be targeted using novel inhibitors or existing drug inhibitors to disable its infection ability altogether. Furthermore, the nanoemulsions, nanospheres, nanoparticles, nano-gels, liposomes, and nanosuspensions can be used for anti-viral drug delivery. This also defines and proposes an approach to address existing key challenges, thus directing scientists worldwide to perhaps refining the delivery of nano-based drugs as a strategy to combat virus outbreaks successfully. Further understanding of the molecular pathology of COVID-19 is expected to help in the discovery and development of drugs against COVID-19. 


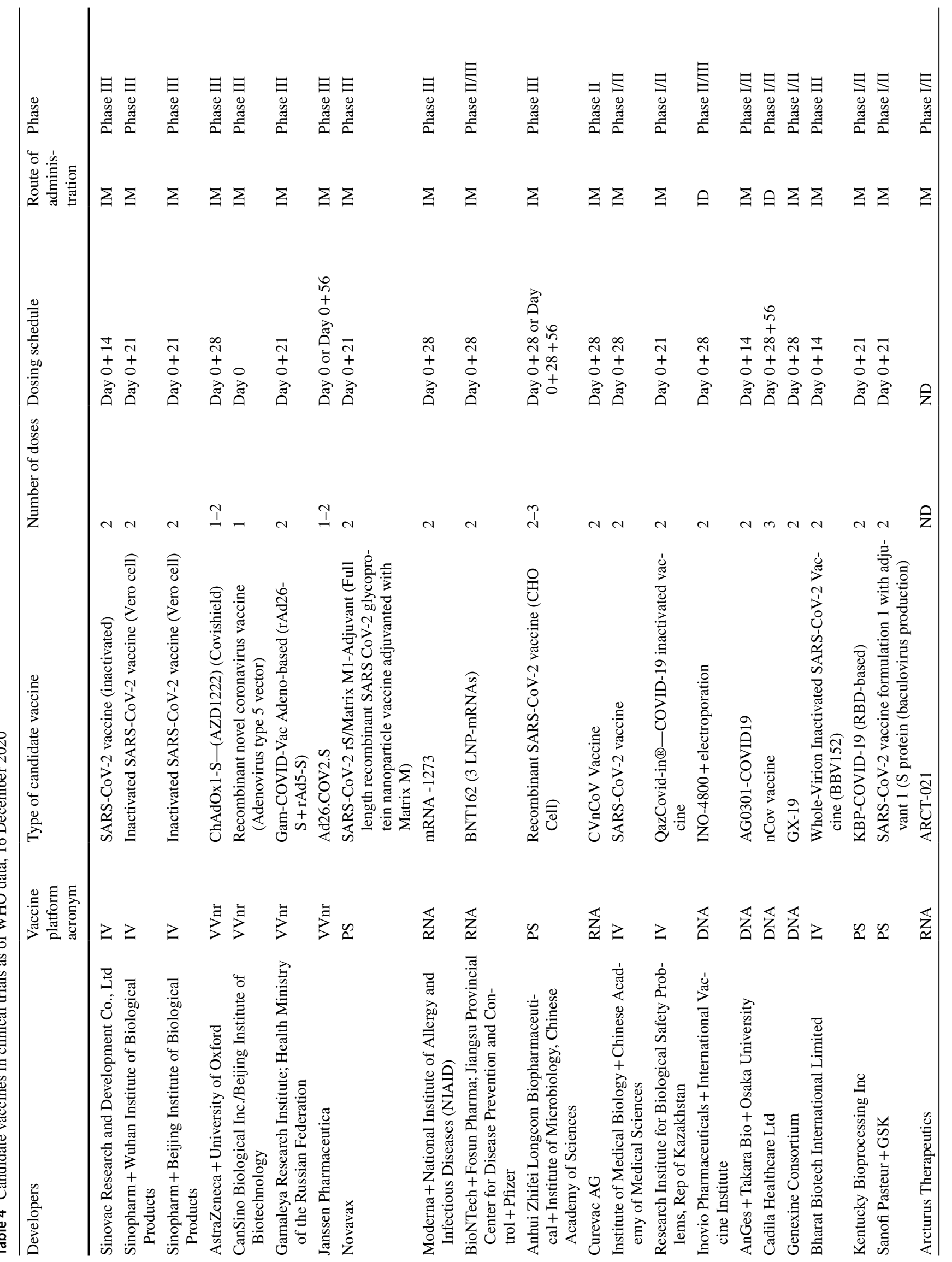




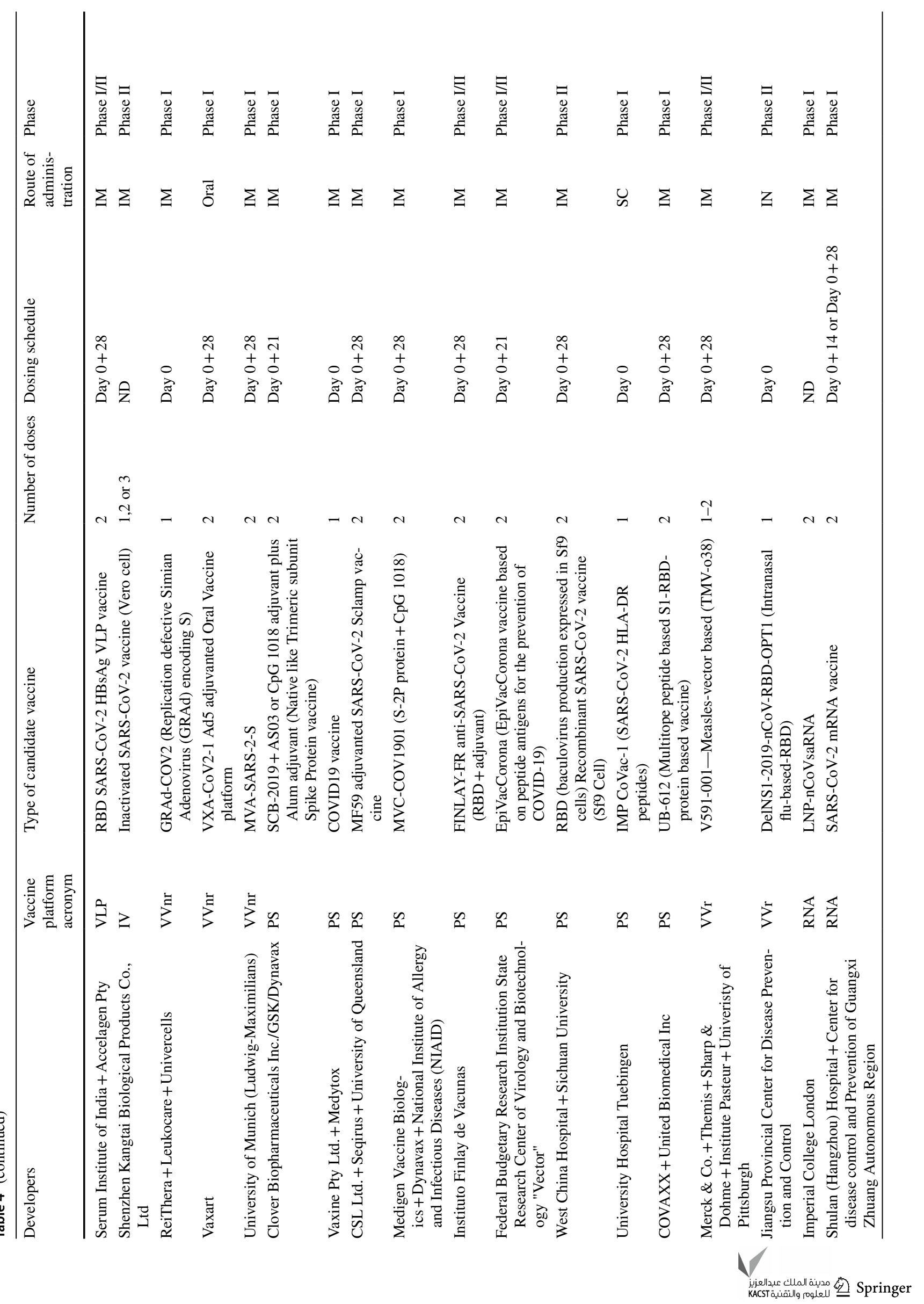




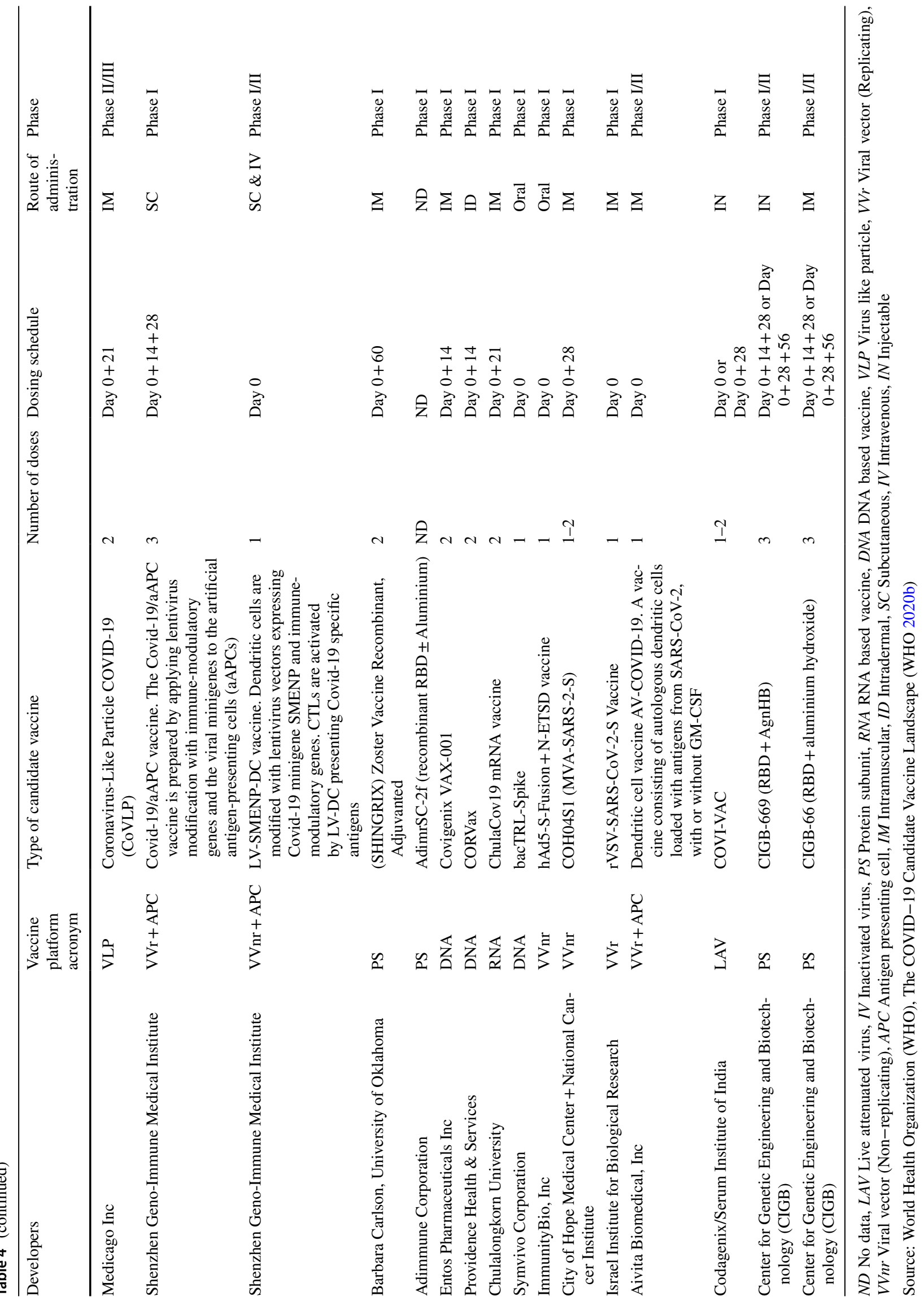


Supplementary Information The online version contains supplementary material available at https://doi.org/10.1007/s13205-021-02749-0.

Acknowledgements Mr. Udhaya Kumar S., one of the authors, gratefully acknowledges the Indian Council of Medical Research (ICMR), India, for providing him a Senior Research Fellowship [ISRM/11(93)/2019]. The authors would like to take this opportunity to thank the management of VIT for providing the necessary facilities and encouragement to carry out this work.

Author contributions SUK, CGPD, and HZ were involved in the design of the review. SUK, DTK, NMP, NJ, SRN, PK, MR, SY, HZ, and CGPD were involved in drafting the manuscript. CGPD, HZ, and MR supervised the entire study design, the acquisition, and the drafting of the manuscript. The manuscript was reviewed and approved by all the authors.

Funding Not applicable for the present study.

\section{Declarations}

Conflict of interest The authors have declared that no conflicts of interest exist.

\section{References}

Ai J-W, Zhang Y, Zhang H-C et al (2020) Era of molecular diagnosis for pathogen identification of unexplained pneumonia, lessons to be learned. Emerg Microbes Infect 9:597-600. https://doi.org/10. 1080/22221751.2020.1738905

Alsamman AM, Zayed H (2020) The transcriptomic profiling of SARSCoV-2 compared to SARS, MERS, EBOV, and H1N1. PLoS ONE. https://doi.org/10.1371/journal.pone.0243270

Angus DC, Derde L, Al-Beidh F et al (2020) Effect of hydrocortisone on mortality and organ support in patients with severe COVID19: The REMAP-CAP COVID-19 corticosteroid domain randomized clinical trial. JAMA 324:1317-1329. https://doi.org/10. 1001/jama.2020.17022

Ansarin K, Tolouian R, Ardalan M et al (2020) Effect of bromhexine on clinical outcomes and mortality in COVID-19 patients: a randomized clinical trial. Bioimpacts 10:209-215. https://doi.org/ 10.34172/bi.2020.27

Ashburn TT, Thor KB (2004) Drug repositioning: identifying and developing new uses for existing drugs. Nat Rev Drug Discov 3:673-683. https://doi.org/10.1038/nrd1468

Ashour HM, Elkhatib WF, Rahman MM, Elshabrawy HA (2020) Insights into the recent 2019 novel coronavirus (SARS-CoV-2) in light of past human coronavirus outbreaks. Pathogens. https:// doi.org/10.3390/pathogens 9030186

Banu S, Jolly B, Mukherjee P et al (2020) A distinct phylogenetic cluster of Indian SARS-CoV-2 isolates. bioRxiv. https://doi.org/ 10.1101/2020.05.31.126136

Behera S, Rana G, Satapathy S et al (2020) Biosensors in diagnosing COVID-19 and recent development. Sens Int 1:100054. https:// doi.org/10.1016/j.sint1.2020.100054

Beigel JH, Nam HH, Adams PL et al (2019) Advances in respiratory virus therapeutics - a meeting report from the 6th isirv Antiviral Group conference. Antiviral Res 167:45-67. https://doi.org/10. 1016/j.antiviral.2019.04.006

Bianchi M, Benvenuto D, Giovanetti M, et al (2020) Sars-CoV-2 Envelope and Membrane Proteins: Structural Differences Linked to Virus Characteristics? In: BioMed Research International. https://www.hindawi.com/journals/bmri/2020/4389089/. Accessed 12 Aug 2020

Biorender (2020) COVID-19 vaccine tracker-BioRender. In: COVID19 vaccine and therapeutic drugs tracker. https://biorender.com/ covid-vaccine-tracker/details/d-CD19/-1. Accessed 28 Dec 2020

Breckenridge A, Jacob R (2019) Overcoming the legal and regulatory barriers to drug repurposing. Nat Rev Drug Discov 18:1-2. https://doi.org/10.1038/nrd.2018.92

Budzilowicz CJ, Wilczynski SP, Weiss SR (1985) Three intergenic regions of coronavirus mouse hepatitis virus strain A59 genome RNA contain a common nucleotide sequence that is homologous to the 3' end of the viral mRNA leader sequence. J Virol 53:834-840

Callaway E, Cyranoski D, Mallapaty S et al (2020) The coronavirus pandemic in five powerful charts. Nature 579:482-483. https:// doi.org/10.1038/d41586-020-00758-2

Caly L, Druce JD, Catton MG et al (2020) The FDA-approved drug ivermectin inhibits the replication of SARS-CoV-2 in vitro. Antiviral Res 178:104787. https://doi.org/10.1016/j.antiviral.2020. 104787

Cao B, Wang Y, Wen D et al (2020) A trial of lopinavir-ritonavir in adults hospitalized with severe covid-19. N Engl J Med 382:1787-1799. https://doi.org/10.1056/NEJMoa2001282

Cascella M, Rajnik M, Cuomo A et al (2020) Features, evaluation and treatment coronavirus (COVID-19). In: StatPearls. StatPearls Publishing, Treasure Island (FL)

Chan JF-W, Kok K-H, Zhu Z et al (2020) Genomic characterization of the 2019 novel human-pathogenic coronavirus isolated from a patient with atypical pneumonia after visiting Wuhan. Emerg Microbes Infect 9:221-236. https://doi.org/10.1080/22221751. 2020.1719902

Chen Y, Guo D (2016) Molecular mechanisms of coronavirus RNA capping and methylation. Virol Sin 31:3-11. https://doi.org/ $10.1007 / \mathrm{s} 12250-016-3726-4$

Chen Y, Liu Q, Guo D (2020) Emerging coronaviruses: genome structure, replication, and pathogenesis. J Med Virol 92:418423. https://doi.org/10.1002/jmv.25681

Clementz MA, Chen Z, Banach BS et al (2010) Deubiquitinating and interferon antagonism activities of coronavirus papainlike proteases. J Virol 84:4619-4629. https://doi.org/10.1128/ JVI.02406-09

Coutard B, Valle C, de Lamballerie X et al (2020) The spike glycoprotein of the new coronavirus 2019-nCoV contains a furinlike cleavage site absent in $\mathrm{CoV}$ of the same clade. Antiviral Res 176:104742. https://doi.org/10.1016/j.antiviral.2020. 104742

Criscuolo A, Gribaldo S (2010) BMGE (Block Mapping and Gathering with Entropy): a new software for selection of phylogenetic informative regions from multiple sequence alignments. BMC Evol Biol 10:210. https://doi.org/10.1186/1471-2148-10-210

Desper R, Gascuel O (2002) Fast and accurate phylogeny reconstruction algorithms based on the minimum-evolution principle. $\mathrm{J}$ Comput Biol 9:687-705. https://doi.org/10.1089/1066527027 61034136

Devaraj SG, Wang N, Chen Z et al (2007) Regulation of IRF-3-dependent innate immunity by the papain-like protease domain of the severe acute respiratory syndrome coronavirus. J Biol Chem 282:32208-32221. https://doi.org/10.1074/jbc.M7048 70200

Dong X, Cao Y, Lu X et al (2020) Eleven faces of coronavirus disease 2019. Allergy 75:1699-1709. https://doi.org/10.1111/all.14289

Ejazi SA, Ghosh S, Ali N (2020) Antibody detection assays for COVID-19 diagnosis: an early overview. Immunol Cell Biol. https://doi.org/10.1111/imcb.12397

Fan H, Ooi A, Tan YW et al (2005) The nucleocapsid protein of coronavirus infectious bronchitis virus: crystal structure of its

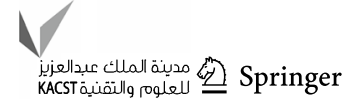


$\mathrm{n}$-terminal domain and multimerization properties. Structure 13:1859-1868. https://doi.org/10.1016/j.str.2005.08.021

Fehr AR, Perlman S (2015) Coronaviruses: an overview of their replication and pathogenesis. Coronaviruses 1282:1-23. https://doi. org/10.1007/978-1-4939-2438-7_1

Forrest LR, Tang CL, Honig B (2006) On the accuracy of homology modeling and sequence alignment methods applied to membrane proteins. Biophys J 91:508-517. https://doi.org/10.1529/bioph ysj.106.082313

Forster P, Forster L, Renfrew C, Forster M (2020) Phylogenetic network analysis of SARS-CoV-2 genomes. Proc Natl Acad Sci USA 117:9241-9243. https://doi.org/10.1073/pnas.2004999117

Frieman M, Ratia K, Johnston RE et al (2009) Severe acute respiratory syndrome coronavirus papain-like protease ubiquitin-like domain and catalytic domain regulate antagonism of IRF3 and NF-kB signaling. J Virol 83:6689-6705. https://doi.org/10.1128/ JVI.02220-08

GISAID (2020) Genomic epidemiology of hCoV-19. https://www. gisaid.org/epiflu-applications/phylodynamics/. Accessed 25 Sept 2020

Gordon DE, Jang GM, Bouhaddou M et al (2020) A SARSCoV-2 protein interaction map reveals targets for drug repurposing. Nature 583:459-468. https://doi.org/10.1038/ s41586-020-2286-9

Guo L, Ren L, Yang S et al (2020) Profiling early humoral response to diagnose novel coronavirus disease (COVID-19). Clin Infect Dis 71:778-785. https://doi.org/10.1093/cid/ciaa310

Habibzadeh P, Stoneman EK (2020) The novel coronavirus: a bird's eye view. Int J Occup Environ Med 11:65-71. https://doi.org/10. 15171/ijoem.2020.1921

Hassan SA, Sheikh FN, Jamal S et al (2020) Coronavirus (COVID-19): a review of clinical features, diagnosis, and treatment. Cureus. https://doi.org/10.7759/cureus.7355

Health C for D and R (2020) Coronavirus Disease 2019 (COVID-19) Emergency use authorizations for medical devices. In: FDA. https://www.fda.gov/medical-devices/emergency-use-authorizat ions-medical-devices/coronavirus-disease-2019-covid-19-emerg ency-use-authorizations-medical-devices. Accessed 21 Dec 2020

Hellewell J, Abbott S, Gimma A et al (2020) Feasibility of controlling COVID-19 outbreaks by isolation of cases and contacts. Lancet Glob Health 8:e488-e496. https://doi.org/10.1016/S2214109X(20)30074-7

Hoffmann M, Kleine-Weber H, Schroeder S et al (2020) SARS-CoV-2 cell entry depends on ACE2 and TMPRSS2 and is blocked by a clinically proven protease inhibitor. Cell 181:271-280.e8. https:// doi.org/10.1016/j.cell.2020.02.052

Horby P, Lim WS, Emberson JR et al (2020) Dexamethasone in hospitalized patients with Covid-19-preliminary report. N Engl J Med. https://doi.org/10.1056/NEJMoa2021436

Hosseiny M, Kooraki S, Gholamrezanezhad A et al (2020) Radiology perspective of coronavirus disease 2019 (COVID-19): lessons from severe acute respiratory syndrome and middle east respiratory syndrome. Am J Roentgenol 214:1078-1082. https://doi. org/10.2214/AJR.20.22969

Huang C, Wang Y, Li X et al (2020a) Clinical features of patients infected with 2019 novel coronavirus in Wuhan, China. Lancet 395:497-506. https://doi.org/10.1016/S0140-6736(20)30183-5

Huang Y, Yang C, Xu X et al (2020b) Structural and functional properties of SARS-CoV-2 spike protein: potential antivirus drug development for COVID-19. Acta Pharmacol Sin 41:1141-1149. https://doi.org/10.1038/s41401-020-0485-4

Jacob JJ, Vasudevan K, Veeraraghavan B et al (2020) Genomic evolution of severe acute respiratory syndrome Coronavirus 2 in India and vaccine impact. Indian J Med Microbiol 38:210. https://doi. org/10.4103/ijmm.IJMM_20_303
Jaimes JA, André NM, Chappie JS et al (2020) Phylogenetic analysis and structural modeling of SARS-CoV-2 spike protein reveals an evolutionary distinct and proteolytically sensitive activation loop. J Mol Biol 432:3309-3325. https://doi.org/10.1016/j.jmb. 2020.04.009

Jeon YJ, Yoo HM, Chung CH (2010) ISG15 and immune diseases. Biochim et Biophys Acta BBA Mol Basis Dis 1802:485-496. https://doi.org/10.1016/j.bbadis.2010.02.006

Jeronimo CMP, Farias MEL, Val FFA et al (2020) Methylprednisolone as adjunctive therapy for patients hospitalized with coronavirus disease 2019 (COVID-19; Metcovid): a randomized double-blind phase IIb placebo-controlled trial. Clin Infect Dis. https://doi.org/ $10.1093 /$ cid/ciaa1177

Ji T, Liu Z, Wang G et al (2020) Detection of COVID-19: a review of the current literature and future perspectives. Biosens Bioelectron 166:112455. https://doi.org/10.1016/j.bios.2020.112455

Junier T, Zdobnov EM (2010) The Newick utilities: high-throughput phylogenetic tree processing in the Unix shell. Bioinformatics 26:1669-1670. https://doi.org/10.1093/bioinformatics/btq243

Katoh K, Standley DM (2013) MAFFT multiple sequence alignment software version 7: improvements in performance and usability. Mol Biol Evol 30:772-780. https://doi.org/10.1093/ molbev/mst010

Kilianski A, Mielech AM, Deng X, Baker SC (2013) Assessing activity and inhibition of middle east respiratory syndrome coronavirus papain-like and 3C-like proteases using luciferasebased biosensors. J Virol 87:11955-11962. https://doi.org/10. 1128/JVI.02105-13

Klausegger A, Strobl B, Regl G et al (1999) Identification of a coronavirus hemagglutinin-esterase with a substrate specificity different from those of influenza $\mathrm{C}$ virus and bovine coronavirus. J Virol 73:3737-3743. https://doi.org/10.1128/JVI.73.5. 3737-3743.1999

Ko W-C, Rolain J-M, Lee N-Y et al (2020) Arguments in favour of remdesivir for treating SARS-CoV-2 infections. Int J Antimicrob Agents 55:105933. https://doi.org/10.1016/j.ijantimicag. 2020.105933

Komander D, Clague MJ, Urbé S (2009) Breaking the chains: structure and function of the deubiquitinases. Nat Rev Mol Cell Biol 10:550-563. https://doi.org/10.1038/nrm2731

Koyama T, Platt D, Parida L (2020) Variant analysis of SARS-CoV-2 genomes. Bull World Health Organ 98:495-504. https://doi. org/10.2471/BLT.20.253591

Kumar SU, Kumar DT, Christopher BP, Doss CGP (2020) The rise and impact of COVID-19 in India. Front Med. https://doi.org/ $10.3389 /$ fmed.2020.00250

Kupferschmidt K, Cohen J (2020) WHO launches global megatrial of the four most promising coronavirus treatments. In: SciencelAAAS. https://www.sciencemag.org/news/2020/03/ who-launches-global-megatrial-four-most-promising-coron avirus-treatments. Accessed 28 Dec 2020

Lai MM, Baric RS, Brayton PR, Stohlman SA (1984) Characterization of leader RNA sequences on the virion and mRNAs of mouse hepatitis virus, a cytoplasmic RNA virus. Proc Natl Acad Sci USA 81:3626-3630. https://doi.org/10.1073/pnas. 81.12.3626

Lai MM, Baric RS, Makino S et al (1985) Recombination between nonsegmented RNA genomes of murine coronaviruses. J Virol 56:449-456. https://doi.org/10.1128/JVI.56.2.449-456.1985

Lambert-Niclot S, Cuffel A, Pape SL et al (2020) Evaluation of a rapid diagnostic assay for detection of SARS-CoV-2 antigen in nasopharyngeal swabs. J Clin Microbiol. https://doi.org/10.1128/ JCM.00977-20

Lefort V, Desper R, Gascuel O (2015) FastME 2.0: a comprehensive, accurate, and fast distance-based phylogeny inference program. 
Mol Biol Evol 32:2798-2800. https://doi.org/10.1093/molbev/ msv150

Lemoine F, Correia D, Lefort V et al (2019) NGPhylogeny.fr: new generation phylogenetic services for non-specialists. Nucleic Acids Res 47:W260-W265. https://doi.org/10.1093/nar/gkz303

Letko M, Marzi A, Munster V (2020) Functional assessment of cell entry and receptor usage for SARS-CoV-2 and other lineage B betacoronaviruses. Nat Microbiol 5:562-569. https://doi.org/10. 1038/s41564-020-0688-y

Letunic I, Bork P (2019) Interactive Tree Of Life (iTOL) v4: recent updates and new developments. Nucleic Acids Res 47:W256W259. https://doi.org/10.1093/nar/gkz239

Li F (2016) Structure, function, and evolution of coronavirus spike proteins. Annu Rev Virol 3:237-261. https://doi.org/10.1146/ annurev-virology-110615-042301

Li G, Clercq ED (2020) Therapeutic options for the 2019 novel coronavirus (2019-nCoV). Nat Rev Drug Discov 19:149-150. https:// doi.org/10.1038/d41573-020-00016-0

Li R, Pei S, Chen B et al (2020c) Substantial undocumented infection facilitates the rapid dissemination of novel coronavirus (SARSCoV-2). Science 368:489-493. https://doi.org/10.1126/science. abb3221

Li X, Song Y, Wong G, Cui J (2020d) Bat origin of a new human coronavirus: there and back again. Sci China Life Sci 63:461462. https://doi.org/10.1007/s11427-020-1645-7

Li Q, Guan X, Wu P et al (2020b) Early transmission dynamics in Wuhan, China, of novel coronavirus-infected pneumonia. N Engl J Med 382:1199-1207. https://doi.org/10.1056/NEJMo a2001316

Li J-Y, You Z, Wang Q et al (2020a) The epidemic of 2019-novelcoronavirus (2019-nCoV) pneumonia and insights for emerging infectious diseases in the future. Microbes Infect. https:// doi.org/10.1016/j.micinf.2020.02.002

Liu C, Zhou Q, Li Y et al (2020) Research and development on therapeutic agents and vaccines for COVID-19 and related human coronavirus diseases. ACS Cent Sci 6:315-331. https://doi.org/ 10.1021/acscentsci.0c00272

Lu H (2020) Drug treatment options for the 2019-new coronavirus (2019-nCoV). Biosci Trends 14:69-71. https://doi.org/10. 5582/bst.2020.01020

Lu R, Zhao X, Li J et al (2020) Genomic characterisation and epidemiology of 2019 novel coronavirus: implications for virus origins and receptor binding. Lancet 395:565-574. https://doi. org/10.1016/S0140-6736(20)30251-8

Martinez MA (2020) Compounds with therapeutic potential against novel respiratory 2019 coronavirus. Antimicrob Agents Chemother. https://doi.org/10.1128/AAC.00399-20

Masters PS (2006) The molecular biology of coronaviruses. In: Advances in virus research. Academic Press, pp 193-292

McBride R, van Zyl M, Fielding BC (2014) The coronavirus nucleocapsid is a multifunctional protein. Viruses 6:2991-3018. https://doi.org/10.3390/v6082991

Milken Institute (2020) COVID-19 Treatment and vaccine tracker. https://covid-19tracker.milkeninstitute.org/. Accessed 28 Dec 2020

Mishra D, Mishra A, Chaturvedi VK, Singh MP (2020) An overview of COVID-19 with an emphasis on computational approach for its preventive intervention. 3 Biotech. https://doi.org/10.1007/ s13205-020-02425-9

MOHFW (2020) India-COVID-19 statewise status. In: MyGov. in. https://mygov.in/corona-data/covid19-statewise-status/. Accessed 21 Dec 2020

Morse JS, Lalonde T, Xu S, Liu WR (2020) Learning from the past: possible urgent prevention and treatment options for severe acute respiratory infections caused by $2019-\mathrm{nCoV}$. ChemBioChem 21:730-738. https://doi.org/10.1002/cbic.202000047
Mousavizadeh L, Ghasemi S (2020) Genotype and phenotype of COVID-19: their roles in pathogenesis. J Microbiol Immunol Infect. https://doi.org/10.1016/j.jmii.2020.03.022

Mullard A (2020) Flooded by the torrent: the COVID-19 drug pipeline. Lancet 395:1245-1246. https://doi.org/10.1016/S01406736(20)30894-1

Nal B, Chan C, Kien F et al (2005) Differential maturation and subcellular localization of severe acute respiratory syndrome coronavirus surface proteins S, M and E. J Gen Virol 86:14231434. https://doi.org/10.1099/vir.0.80671-0

NGS (2020) First NGS-based COVID-19 diagnostic. Nat Biotechnol 38:777-777. https://doi.org/10.1038/s41587-020-0608-y

Nie Q, Li X, Chen W et al (2020) Phylogenetic and phylodynamic analyses of SARS-CoV-2. Virus Res 287:198098. https://doi. org/10.1016/j.virusres.2020.198098

Pammolli F, Magazzini L, Riccaboni M (2011) The productivity crisis in pharmaceutical R\&D. Nat Rev Drug Discov 10:428-438. https://doi.org/10.1038/nrd3405

Parameshwar K, Pamu S, Sandeep K, Suresh C (2020) A review novel coronavirus. Asian J Pharmaceut Clin Res. https://doi. org/10.22159/ajpcr.2020.v13i4.36982

Patick AK, Potts KE (1998) Protease inhibitors as antiviral agents. Clin Microbiol Rev 11:614-627. https://doi.org/10.1128/CMR. 11.4.614

Pereson MJ, Mojsiejczuk L, Martínez AP et al (2021) Phylogenetic analysis of SARS-CoV-2 in the first few months since its emergence. J Med Virol. https://doi.org/10.1002/jmv.26545

Prajapat M, Sarma P, Shekhar N et al (2020a) Update on the target structures of SARS-CoV-2: a systematic review. Indian J Pharmacol 52:142-149. https://doi.org/10.4103/ijp.IJP_338_20

Prajapat M, Sarma P, Shekhar N et al (2020b) Drug targets for corona virus: a systematic review. Indian J Pharmacol 52:56-65. https:// doi.org/10.4103/ijp.IJP_115_20

Pushpakom S, Iorio F, Eyers PA et al (2019) Drug repurposing: progress, challenges and recommendations. Nat Rev Drug Discov 18:41-58. https://doi.org/10.1038/nrd.2018.168

Ramajayam R, Tan K-P, Liang P-H (2011) Recent development of $3 \mathrm{C}$ and $3 \mathrm{CL}$ protease inhibitors for anti-coronavirus and antipicornavirus drug discovery. Biochem Soc Trans 39:1371-1375. https://doi.org/10.1042/BST0391371

Robson B (2020) COVID-19 Coronavirus spike protein analysis for synthetic vaccines, a peptidomimetic antagonist, and therapeutic drugs, and analysis of a proposed achilles' heel conserved region to minimize probability of escape mutations and drug resistance. Comput Biol Med 121:103749. https://doi.org/10.1016/j.compb iomed.2020.103749

Sahin AR, Erdogan A, Mutlu Agaoglu P et al (2020) 2019 novel coronavirus (COVID-19) outbreak: a review of the current literature. EJMO 4:1-7. https://doi.org/10.14744/ejmo.2020.12220/

Schoeman D, Fielding BC (2019) Coronavirus envelope protein: current knowledge. Virol J 16:69. https://doi.org/10.1186/ s12985-019-1182-0

Shey M, Okeibunor JC, Yahaya AA et al (2020) Genome sequencing and the diagnosis of novel coronavirus (SARS-COV-2) in Africa: how far are we? Pan Afr Med J. https://doi.org/10.11604/pamj. 2020.36.80.23723

Singh N, Rai S, Singh V, Singh MP (2020) Molecular characterization, pathogen-host interaction pathway and in silico approaches for vaccine design against COVID-19. J Chem Neuroanat 110:101874-101874. https://doi.org/10.1016/j.jchemneu.2020. 101874

Sola I, Moreno JL, Zúñiga S et al (2005) Role of nucleotides immediately flanking the transcription-regulating sequence core in coronavirus subgenomic mRNA synthesis. J Virol 79:2506-2516. https://doi.org/10.1128/JVI.79.4.2506-2516.2005

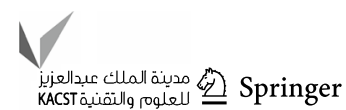


Spaan W, Delius H, Skinner M et al (1983) Coronavirus mRNA synthesis involves fusion of non-contiguous sequences. EMBO J 2:1839-1844. https://doi.org/10.1002/j.1460-2075.1983.tb016 67.x

Tang X, Wu C, Li X et al (2020) On the origin and continuing evolution of SARS-CoV-2. Natl Sci Rev 7:1012-1023. https://doi.org/10. 1093/nsr/nwaa036

Thirumal KD, Shaikh N, Udhaya Kumar S et al (2021) Structure-based virtual screening to identify novel potential compound as an alternative to remdesivir to overcome the RdRp protein mutations in SARS-CoV-2. Front Mol Biosci. https://doi.org/10.3389/ fmolb.2021.645216

Thomas S (2020) The structure of the membrane protein of SARSCoV-2 resembles the sugar transporter SemiSWEET. Pathog Immun 5:342-363. https://doi.org/10.20411/pai.v5i1.377

Tomazini BM, Maia IS, Cavalcanti AB et al (2020) Effect of dexamethasone on days alive and ventilator-free in patients with moderate or severe acute respiratory distress syndrome and COVID-19: the CoDEX randomized clinical trial. JAMA 324:1307-1316. https://doi.org/10.1001/jama.2020.17021

Udhaya Kumar S, Thirumal Kumar D, Siva R, George Priya Doss C (2020) Kerala, India's front runner in novel coronavirus disease (COVID-19). Front Med. https://doi.org/10.3389/fmed.2020. 00355

van Boheemen S, de Graaf M, Lauber C et al (2012) Genomic characterization of a newly discovered coronavirus associated with acute respiratory distress syndrome in humans. MBio. https:// doi.org/10.1128/mBio.00473-12

Walls AC, Park Y-J, Tortorici MA et al (2020) Structure, function, and antigenicity of the SARS-CoV-2 Spike glycoprotein. Cell 181:281-292.e6. https://doi.org/10.1016/j.cell.2020.02.058

Wang D, Hu B, Hu C et al (2020a) Clinical characteristics of 138 hospitalized patients with 2019 novel coronavirus-infected pneumonia in Wuhan, China. JAMA 323:1061-1069. https://doi.org/ 10.1001/jama.2020.1585

Wang M, Cao R, Zhang L et al (2020b) Remdesivir and chloroquine effectively inhibit the recently emerged novel coronavirus (2019$\mathrm{nCoV}$ ) in vitro. Cell Res 30:269-271. https://doi.org/10.1038/ s41422-020-0282-0

Wang Y, Zhang D, Du G et al (2020c) Remdesivir in adults with severe COVID-19: a randomised, double-blind, placebo-controlled, multicentre trial. Lancet 395:1569-1578. https://doi.org/10.1016/ S0140-6736(20)31022-9

Waring MJ, Arrowsmith J, Leach AR et al (2015) An analysis of the attrition of drug candidates from four major pharmaceutical companies. Nat Rev Drug Discov 14:475-486. https://doi.org/ $10.1038 / \mathrm{nrd} 4609$

WHO (2020a) WHO Coronavirus Disease (COVID-19) Dashboard I WHO Coronavirus Disease (COVID-19) Dashboard. https:// covid19.who.int/table. Accessed 29 Dec 2020

WHO (2020b) The COVID-19 candidate vaccine landscape. https:// www.who.int/publications/m/item/draft-landscape-of-covid-19candidate-vaccines. Accessed 28 Dec 2020

Wrapp D, Wang N, Corbett KS et al (2020) Cryo-EM structure of the 2019-nCoV spike in the prefusion conformation. Science 367:1260-1263. https://doi.org/10.1126/science.abb2507

Wu R, Wang L, Kuo H-CD et al (2020) An update on current therapeutic drugs treating COVID-19. Curr Pharmacol Rep. https:// doi.org/10.1007/s40495-020-00216-7

Xu X, Han M, Li T et al (2020) Effective treatment of severe COVID19 patients with tocilizumab. PNAS 117:10970-10975. https:// doi.org/10.1073/pnas.2005615117

$\mathrm{Xu}$ J, Zhao S, Teng T et al (2020) Systematic comparison of two animal-to-human transmitted human coronaviruses: SARS-CoV-2 and SARS-CoV. Viruses. https://doi.org/10.3390/v12020244

Yount B, Curtis KM, Baric RS (2000) Strategy for systematic assembly of large RNA and DNA genomes: transmissible gastroenteritis virus model. J Virol 74:10600-10611. https://doi.org/10.1128/ JVI.74.22.10600-10611.2000

Zeng W, Liu G, Ma H et al (2020) Biochemical characterization of SARS-CoV-2 nucleocapsid protein. Biochem Biophys Res Commun 527:618-623. https://doi.org/10.1016/j.bbrc.2020.04.136

Zhang C, Zheng W, Huang X et al (2020) Protein structure and sequence reanalysis of 2019-nCoV genome refutes snakes as its intermediate host and the unique similarity between its spike protein insertions and HIV-1. J Proteome Res 19:1351-1360. https://doi.org/10.1021/acs.jproteome.0c00129

Zou L, Ruan F, Huang M et al (2020) SARS-CoV-2 viral load in upper respiratory specimens of infected patients. N Engl J Med 382:1177-1179. https://doi.org/10.1056/NEJMc2001737 